The Experimental Engineering Section Off-Gas Decontamination Facility's

\title{
Fractionator Column:
} Installation and Performance

\author{
T. M. Gilliam \\ V. L. Fowler \\ D. J. Inman
}




\section{DISCLAIMER}

This report was prepared as an account of work sponsored by an agency of the United States Government. Neither the United States Government nor any agency Thereof, nor any of their employees, makes any warranty, express or implied, or assumes any legal liability or responsibility for the accuracy, completeness, or usefulness of any information, apparatus, product, or process disclosed, or represents that its use would not infringe privately owned rights. Reference herein to any specific commercial product, process, or service by trade name, trademark, manufacturer, or otherwise does not necessarily constitute or imply its endorsement, recommendation, or favoring by the United States Government or any agency thereof. The views and opinions of authors expressed herein do not necessarily state or reflect those of the United States Government or any agency thereof. 


\section{DISCLAIMER}

Portions of this document may be illegible in electronic image products. Images are produced from the best available original document. 


\section{Printed in the United States of America. Available from}

National Technical Information Service

U.S. Department of Ciommerce

5285 Port Royal Road, Springfield, Virginia 22161

Price: Printed Copy $\$ 6.00$; Microfiche $\$ 3.00$

This report was prepared as an account of work sponsored by an agency of the United States Government. Neither the United States Government nor any agency thereof, nor any of their employees, contractors, subcontractors, or their employees, makes any warranty, express or implied, nor assumes any legal liability or responsibility for any third party's use or the results of such use of any information, apparatus, product or process disclosed in this report, nor represents that its use by such third party would not infringe privately owned rights. 
ORNL/TM-5869

Dist. Category UC-77

Contract No. W-7405-eng-26

CHEMICAL TECHNOLOGY DIVISION

HTGR FUEL RECYCLE PROGRAM (189a OHO45)

Reprocessing Development - Task 300

THE EXPERIMENTAL ENGINEERING SECTION OFF-GAS DECONTAMINATION FACILITY'S FRACTIONATOR COLUMN: INSTALLATION AND PERFORMANCE

T. M. Gilliam, V. L. Fowler, and D. J. Inman

Date Published: March 1978

NOTICE This document contains information of a preliminary nature.

it is subject to révision or correction and therefore does not represent a final report.

OAK RIDGE NATIONAL LABORATORY

Oak Ridge, Tennessee 37830

operated by

UNION CARBIDE CORPORATION

for the

-DEPARTMENT OF ENERGY 
THIS PAGE

WAS INTENTIONALLY

LEFT BLANK 
TABLE OF CONTENTS

$\underline{\text { Page }}$

ABSTRACT. . . . . . . . . . . . . . . . . . 1

1. INTRODUCTION. . . . . . . . . . . . . . . . 2

2. DESCRIPTION OF PROCESS COMPONENTS . . . . . . . . . . . . . 2

3. FLOODING STUDIES. . . . . . . . . . . . . . . 3

4. MASS TRANSFER STUdIES . . . . . . . . . . . . . 12

5. MASS TRANSFER DATA. . . . . . . . . . . . . . . 14

5.1 Stripping Studies. . . . . . . . . . . . 15

5.2 Fractionation Studies. . . . . . . . . . 18

6. CONCLUSIONS AND RECOMMENDATIONS . . . . . . . . . . 25

REFERENCES. . . . . . . . . . . . . . . . . 29

APPENDIXES. . . . . . . . . . . . . . . . . . . 31

Appendix A: Detailed Component Description . . . . . . 33

A.1 Fractionator Column . . . . . . . . . 33

A.2 Fractionator Reboiler . . . . . . . . 36

A.3 Fractionator Column Reflux Station. . . . . . 38

A.4 Fractionator Column Condenser ......... 40

A.5 Refrigeration .............. 42

A.6 Process Instrumentation and Controls. . . . . 42

A.7 Process Monitoring and Sampling . . . . . . 46

A.8 References for Appendix A . . . . . . . . 46

Append1x B: Flooding Experiments . . . . . . . . . 47

B.1 Flooding Point Determination. . . ..... . 47

B.2 References for Appendix B . . . . . . . 52 
TABLE OF CONTENTS (cont'd)

Page

Appendix C: Mass Transfer Calculations. . . . . . . 57

C.1. Stripping Studies. . . . . . . . . . . 57

C.2 Fractionation Studies. . . . . . . . . 66

C.3 References for Appendix C. . . . . . . . . 74 
THE EXPERIMENTAL ENGINEERING SECTION OFF-GAS DECONTAMINATION FACILITY'S FRACTIONATOR COLUMN: INSTALLATION AND PERFORMANCE

T. M. Gilliam, V. L. Fowler, and D. J. Inman

\section{ABSTRACT}

A detailed description of the third column recently. installed in the Experimental Engineering Section Off-Gas Decontamination Facility (EES-ODF) is presented. The EESODF is being used to provide engineering-scale experiments (nominal gas and liquid flows of $5 \mathrm{scfm}$ and $0.5 \mathrm{gpm}$, respectively) in the development of the Krypton Absorption in Liquid $\mathrm{CO}_{2}$ (KALC) process.

A detailed discussion of the column's construction is provided. This discussion includes the peripherals associated with the column, such as refrigeration, heat exchangers, instrumentation, etc:

The compressibility of Goodloe packing (the packing in the other columns) and the pussible reduced throughput due to this compression have revealed the desirability of a random (i.e., noncompressible) packing. Toward this end, the third column is packed with a new random packing (PRO-PAK). A preliminary comparison between this packing and the woven wire mesh packing (Goodloe) used in the other two columns has been made. Experiments comparing the throughput capacity indicate that the PRO-PAK packing has approximately $60 \%$ the capacity of Goodloe for a $\mathrm{CO}_{2}$ system. When used as a fractionator or stripper with the basic $\mathrm{O}_{2}-\mathrm{Kr}-\mathrm{CO}_{2} \mathrm{KALC}$ system, the PRO-PAK column produced HTU values less than or equal to the Goodloe columns under similar operating conditions. 


\section{INTRODUCTION}

As part of the HTGR Fuel Recycle Program, ${ }^{1,2}$ development work is being performed on the KALC (Krypton Absorption in Liquid $\underline{\mathrm{CO}}_{2}$ ) process. The KALC process is being developed as a means of removing and concentrating ${ }^{85} \mathrm{Kr}$ from the off-gas generated during the reprocessing of HTGR fuel elements.

In previous experimental campaigns (II and III), ${ }^{3,4}$ mass transfer and fluid dynamics data were collected using a two-column system. The two-column system has been described previously ${ }^{5}$ in great detail and will be discussed only as needed for the clarification of data presented in this report.

The primary objective of Campaign IV (i.e., experiments performed between August 1, 1976, and September 31, 1977) was to obtain data on the effect of minor components on the basic KALC operations. 'Toward this end, an additional column, packed with a new random packing (PROPAK), was installed to give the Experimental Engineering Section offGas Decontamination Facility (EES-ODF) the capability of three-column operations. This report deals with the installation and performance of the new column.

\section{DESCRIPTION OF PROCESS COMFONENTS}

All of the major pressure vessels described in this report were designed and fabricated to withstand the elevated operating pressures of the facility. Typically, each drawing contains a nozzle identification schedule, a parts list, and notes on fabrication and testing. 
The material of construction, 304L stainless steel, was used throughout the process for both vessels and piping (unless otherwise specified). Refrigerant lines external to the process vessels are made of copper. All welded construction is used exclusively except where threaded connections are required for instrumentation.

Packed columns in the EES-ODF are named in accordance with the primary experimental role they will play in the overall KALC process development. The new column is used primarily for the study of fractionating the dissolved light gases from the ${ }^{85} \mathrm{Kr}-1$ aden $\mathrm{CO}_{2}$ solvent. Consequent1y, it will be referred to as the fractionator.

The fractionator is nominally 2 in. in diam and $9 \mathrm{ft}$ in height. Appendix A provides a detailed description of the fractionator, as well as the peripherals associated with the column, including refrigeration, heat exchangers, instrumentation, etc.

\section{FLOODING STUDIES}

In the past, the Goodloe wire mesh packing ${ }^{6}$ (Fig. 1) used in the absorber and stripper columns has become distorted ${ }^{4,7}$ to the extent that the gas throughput of the two columns was reduced to $15 \%$ of that predicted by the manufacturer. The compressibility of the packing and the possible reduced throughput due to this compression have revealed the desirability of a random (i.e., noncompressible) packing with comparable throughput and mass transfer characteristics.

Toward this end, the 2-in. fractionator column was filled to a height of $8.9 \mathrm{ft}$ with PRO-PAK packing ${ }^{8}$ (Fig. 2). As with the other 


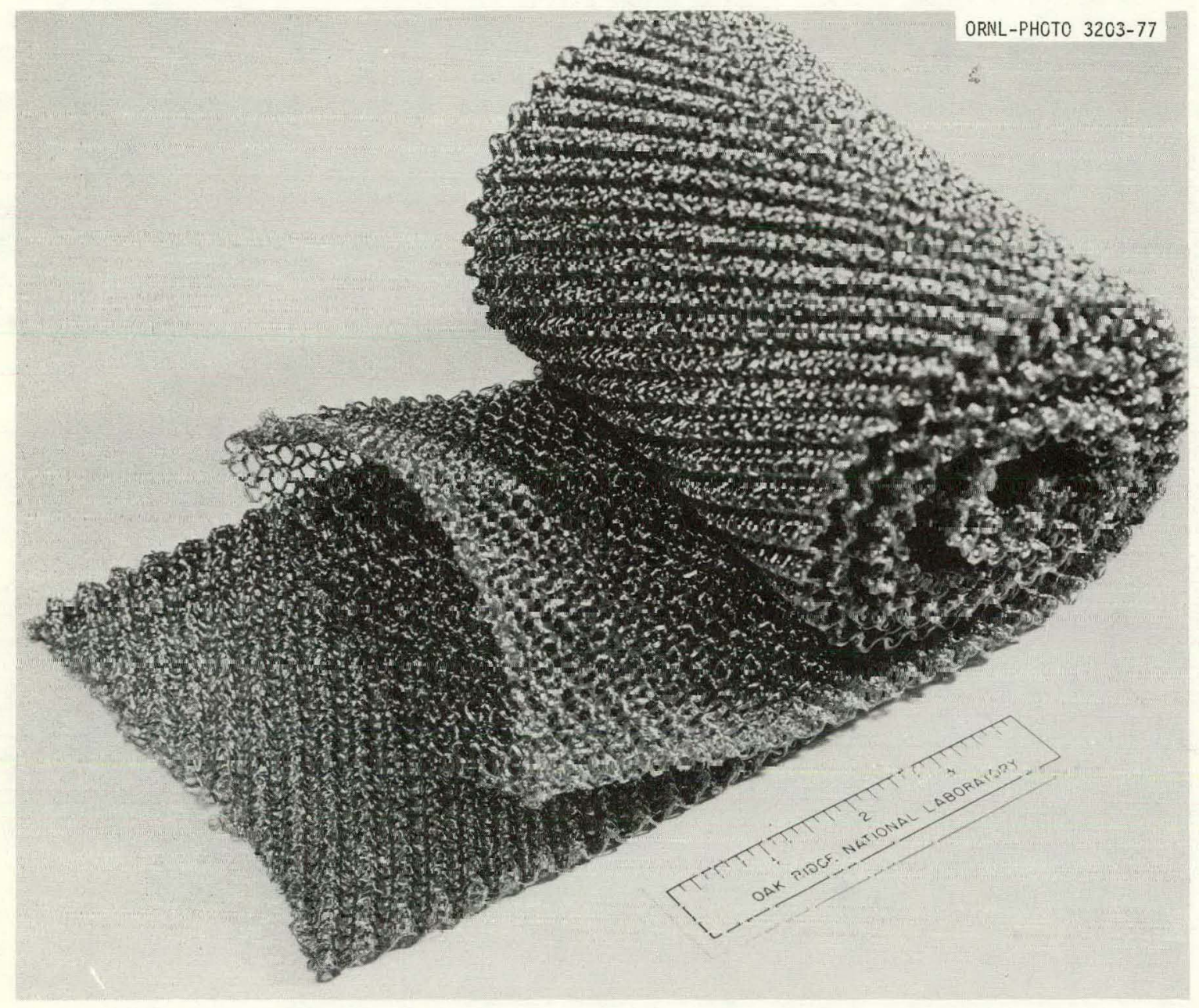

Fig. 1. Goodloe packing. 


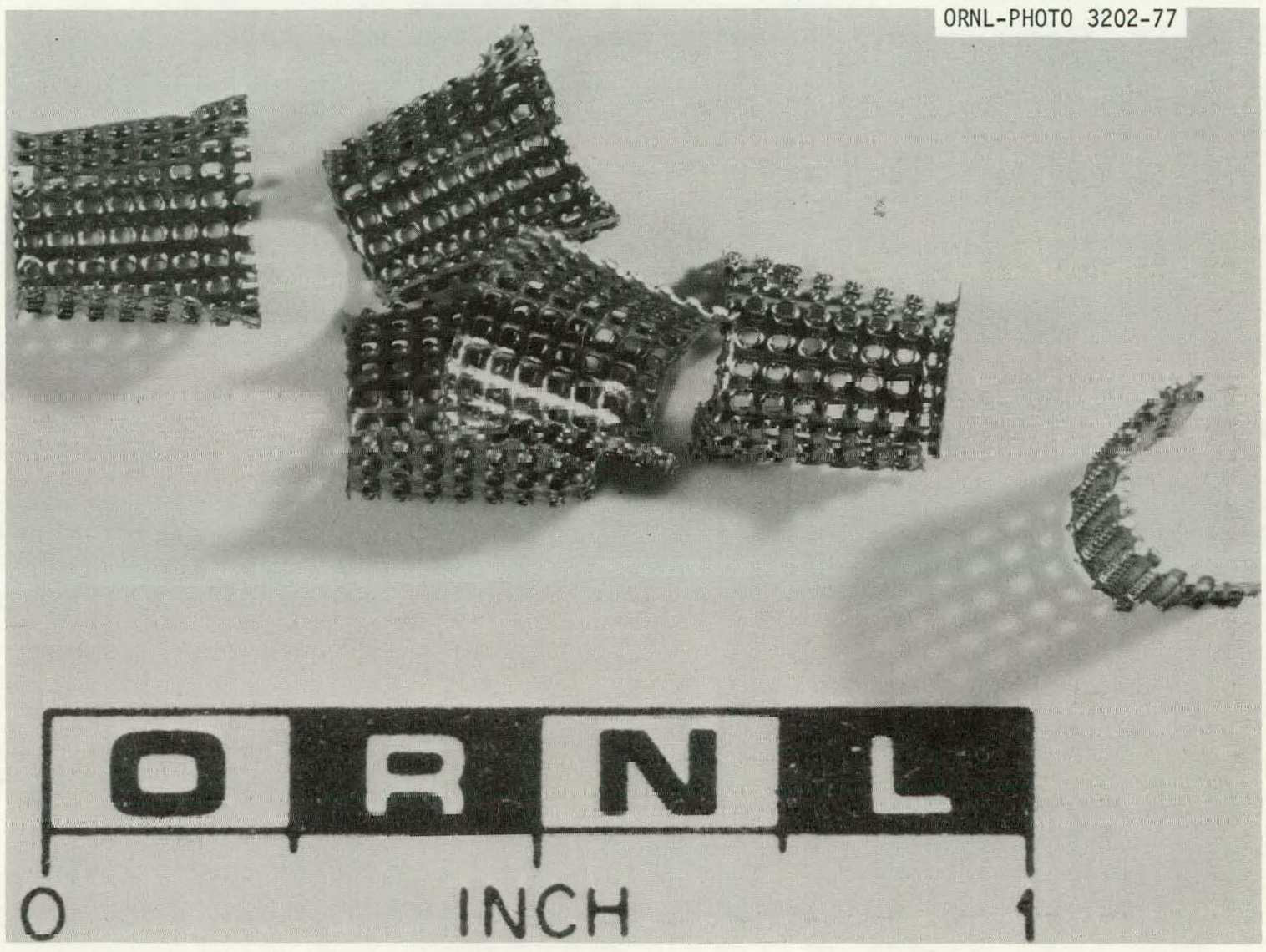

Fig. 2. PRO-PAK packing. 
two columns, the packing was installed in three sections located between the intracolumn samplers (Fig. A-1, Appendix A). A flat wire mesh distributor along with a conical (point upward) wire mesh packing support was installed above and below each section of packing. The PRO-PAK packing is a random packing consisting of thin 0.24-in. by 0.24-in. nickel units. The metal has 1024 holes per square inch and is shaped into half cyliuders with corncrs or edges bent inward to prevent nesting of one piece within anothcr. The holes are not clean cut and have a protrusion (or burr) extending from one side.

The flooding studies were performed using saturated $\mathrm{CO}_{2}$ with the column operating in total reflux (i.e., no off-gas). The column was considered to be flooded when the pressure drop across the column became greater than $10 \mathrm{in} . \mathrm{H}_{2} \mathrm{O}$. The flooding points were obtained by increasing the boilup rate, at a fixed pump rate, until the desired pressure drop across the column was obtained. A detailed discussion of the flooding point determination is shown in Appendix B.

A summary of the nominal flooding points are presented in Table 1. The experimental flooding data was fit to an equation of the following form:

$$
\bar{y}=A+B(\bar{x})+C(\bar{x})^{2}
$$

where

$$
\begin{aligned}
& \bar{y}=\log \left[\frac{U_{m}{ }^{2} \rho_{G} \mu_{L}{ }^{0.2}}{g \rho_{L}}\right], \\
& \bar{x}=2.0+\log \left[\frac{L}{G} \sqrt{\rho_{G} / \rho_{L}}\right],
\end{aligned}
$$


Table 1. Sunmary of PRO-PAK flooding data

\begin{tabular}{cccc}
\hline $\begin{array}{c}\text { Column } \\
\text { pressure } \\
(\mathrm{atm})\end{array}$ & $\begin{array}{c}\text { Average column } \\
\text { temperature } \\
\left({ }^{\circ} \mathrm{C}\right)\end{array}$ & $\frac{\mathrm{L}}{\mathrm{G}} \sqrt{\frac{\rho_{\mathrm{G}}}{\rho_{\mathrm{L}}}}$ & $\frac{\mathrm{U}_{\mathrm{m}}{ }^{2} \rho_{\mathrm{G}} \mu_{\mathrm{L}}{ }^{0.2}}{\mathrm{~g} \rho_{\mathrm{L}}}$ \\
\hline 20 & -18.8 & 1.44 & 0.0000248 \\
20 & -18.8 & 2.26 & 0.00001 .55 \\
20 & -18.8 & 3.91 & 0.0000075 \\
20 & -19.0 & 3.68 & 0.0000083 \\
20 & -19.1 & 5.20 & 0.0000057 \\
20 & -18.0 & 1.84 & 0.0000194 \\
20 & -18.2 & 2.87 & 0.0000117 \\
20 & -18.2 & 4.52 & 0.0000066 \\
\hline
\end{tabular}




$$
\begin{aligned}
A & =-2.738, \\
B & =-0.607, \\
C & =-0.118, \\
U_{m} & =\text { vapor velocity, } \mathrm{ft} / \mathrm{sec}, \\
\rho_{G} & =\text { vapor-phase density, } 1 \mathrm{~b} / \mathrm{ft}^{3}, \\
\mu_{L} & =1 \text { iquid-phase viscosity, } \mathrm{cP}, \\
g & =\text { conetant, } 32.2 \mathrm{ft} / \mathrm{gcc}{ }^{2}, \\
\rho_{L} & =1 \text { iquid-phase density, } 1 \mathrm{~b} / \mathrm{ft}^{3}, \\
L & =1 \text { iquid rate, } 1 \mathrm{~b} / \mathrm{hr} \cdot \mathrm{ft}^{2}, \\
G & =\text { vapor rate, } \mathrm{lb} / \mathrm{hr} \cdot \mathrm{ft}^{2} .
\end{aligned}
$$

Figure 3 presents a comparison between the experimentally determined PRO-PAK and Goodloe 4 flooding correlations. The figure shows that PROPAK has approximately $60 \%$ the throughput capacity of the Goodloe packing.

Figure 4 presents a comparison between the flooding data obtained (as well as the resulting empirical correlation) and the predicted correlation of the manufacturer. The discrepancy between the experimental and predicted throughput is not a major concern because the manufacturer's correlation, 9

$$
G=270\left(\Omega_{L}\right)^{0.58}\left(\rho_{G}\right)^{0.42}
$$

where

$$
\begin{aligned}
& G=\text { mass vapor velocity, } 1 \mathrm{~b} / \mathrm{hr} \cdot \mathrm{ft}^{2}, \\
& \rho_{L}=\text { density of liquid phase, } 1 \mathrm{~b} / \mathrm{ft}^{3}, \\
& \rho_{G}=\text { density of vapor phase, } 1 \mathrm{~b} / \mathrm{ft}^{3},
\end{aligned}
$$




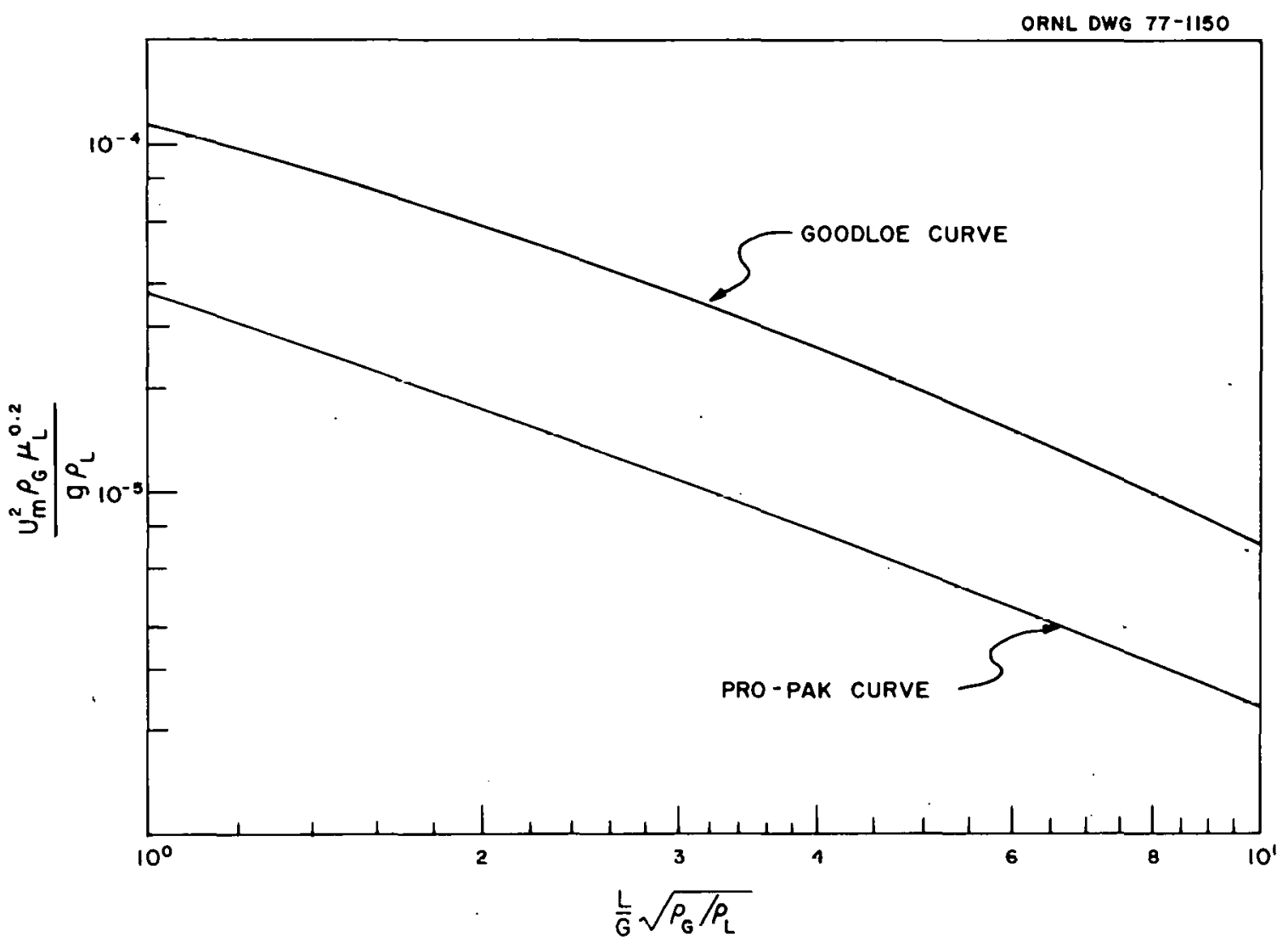

Fig. 3. A comparison between PRO-PAK and Goodloe experimental flooding curves. 


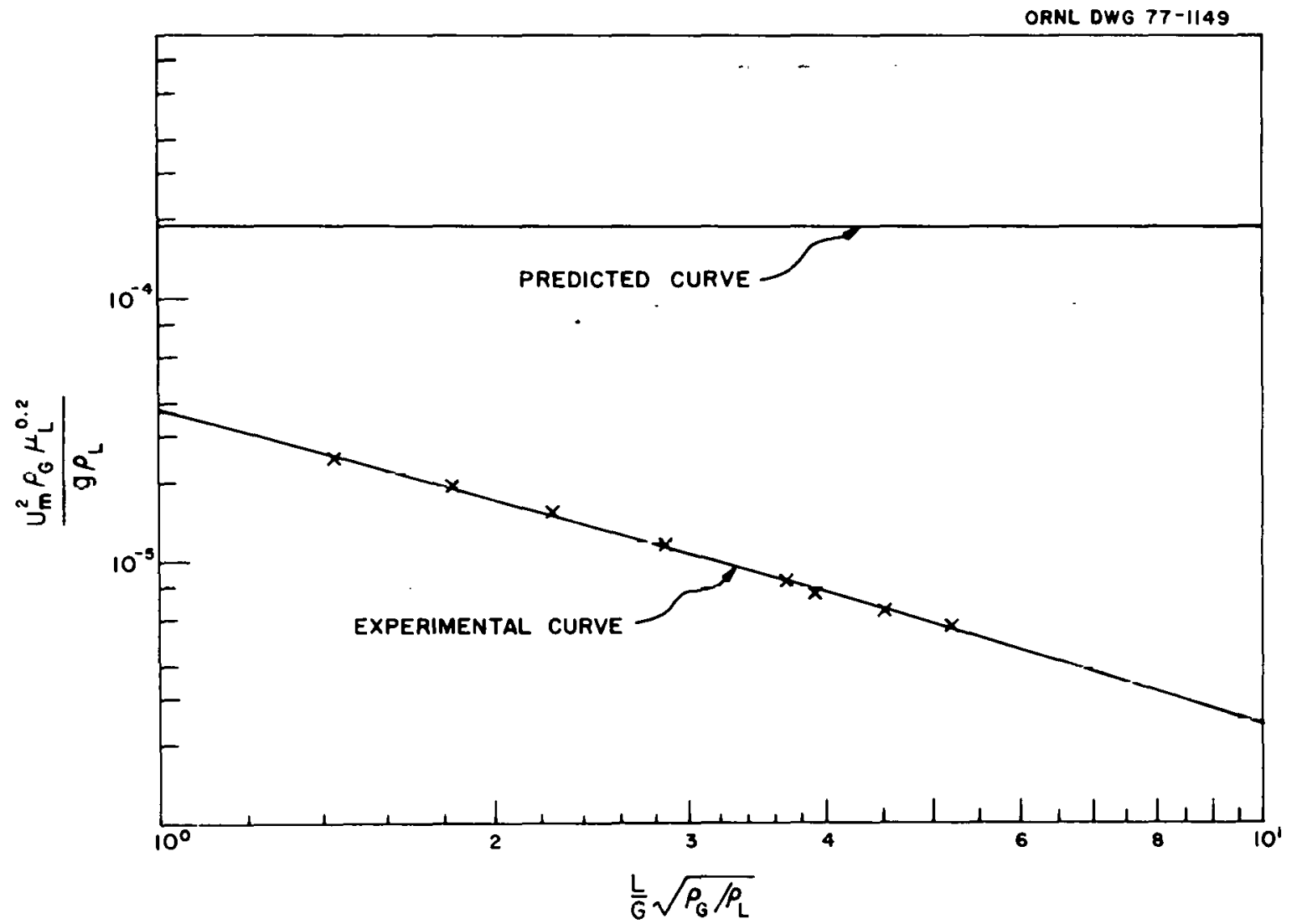

Fig. 4. A comparison between the experimental and predicted PRO PAK flooding curvcs. 
disagrees with the accepted correlations of Sherwood ${ }^{10}$ and Eckert ${ }^{11}$ which state that flooding velocity is a function of liquid and vapor rate. This relationship has also been seen experimentally in the KALC facility. ${ }^{4}$ of some concern, however, is the fact that the experimental throughput for both types of packing is at most $50 \%$ of the throughput predicted by the manufacturers. Experimental throughputs approaching the predicted values have been obtained previously for columns packed with Goodloe packing using air-water ${ }^{12}$ and air--Freon-12 (see ref. 13) systems. This indicates that perhaps a fundamental physical property is missing from the flooding correlation which would account for this discrepancy. One such variable might be the liquid surface tension $(\sigma)$ of the system. For the air-water and air-Freon system, as well as the benzene-ethylene dichloride and $\underline{N}$-heptane-methyl cyclohexane systems used in the manufacturers' correlation for Goodloe and PRO-PAK packing, respectively, the liquid surface tension was between 10 and 100 dynes/cm; ${ }^{14,15}$ the surface tension of liquid $\mathrm{CO}_{2}$ is $<1.0$ dyne/cm. 16 Investigations in this area have been limited. Newton ${ }^{17}$ varied the liquid surface tension of an air-water system by the introduction of controlled quancities of surfactants (Sterox SK) and found that the flooding velocity was a function of $\sigma^{3}$.

Newton determined that flooding velocity decreased with decreasing values for liquid surface tension. This would tend to explain why the $\mathrm{CO}_{2}$ data (low surface tension) is substantially less than the other systems (high surface tension), indicating that any generalized flooding correlation for PRO-PAK or Goodloe should include liquid surface tension as a variable. 


\section{MASS TRANSFER STUDIES}

Although the addition of the third column gave the EES-ODF the capability of studying the overall performance of the three-column KALC system, the ability to operate a two-column system has been retained. Specifically, the system can be operated in one of three ways: (1) in a three-column mode with the absorber, fractionator, and stripper in series, (2) in a two-column mode with the absorber and fractionator in series, or

(3) in a two-column mode with the absorber and stripper in series.

Experiments were performed using a $\mathrm{CO}_{2}-\mathrm{O}_{2}-\mathrm{Kr}$ system at conditions similar to those in Campaign III so that a preliminary comparison between the mass transfer characteristics of the PRO-PAK and Goodloe packings could be made. Specifically, experiments were performed to compare the two packings during fractionation and stripping operations. For the mass transfer studies during stripping, the system was operaced In d two-column mode consisting of the absorber and tractionator. For mass transfer studies during fractionation, a three-column system was used.

During the operations, the system feed-gas (consisting of $>90 \%$ $\mathrm{CO}_{2},<10 \% \mathrm{O}_{2}$, and tracer levels of ${ }^{85} \mathrm{Kr}$ ) was compressed to a pressure slightly higher than the absorber operating pressure and then routed to the bottom of the absorber. As the gas travels up the absorber column, it is contacted with a counterrurrent stream of liquid carbon dioxide. The liquid stream absorbs essentially all of the krypton and a large portion of the oxygen, as well. The solute-laden liquid is then routed to the top of the fractionator by an operating pressure differential 
(nominally $2 \mathrm{~atm}$ ) between the two columns. In the fractionator column, the dissolved gas is distilled and leaves the column via the fractionator off-gas. The liquid leaving the bottom of the fractionator is relatively free of solute during stripping studies and is pumped to the top of the absorber as scrub liquid. During fractionator studies, the liquid is routed to the top of the stripper where the remaining dissolved gases are distilled and exit via the stripper off-gas. The liquid leaving the bottom of the stripper is then recycled back to the absorber to act as liquid scrub. In both stripping and fractionation experiments, the column off-gas streams were routed to a compressor where they combine to form the system feed-gas.

As with all mass transfer operations, some operating variables are designated as independent, and others are designated as dependent. Since the analysis was performed during "steady-state," the choice of independent-dependent operating variables became academic. Therefore, during the experiments, the independent variables were chosen on the basis of their ability to be maintained at a desired value.

The variable of primary concern in the operation of the columns was the liquid-to-vapor ratio, the liquid rate being determined by the pump rate. The vapor rate in the absorber column was fixed by controlling the feed-gas rate. The off-gas rate was set manually to complement the feed-gas rate (nominally $80 \%$ of feed rate). The absorber pressure and temperature were then allowed to seek their own levels. The fractionator column pressure was set by controlling the amount of refrigerant to the condenser. The fractionator temperature was allowed 
to seek its own level. During fractionation studies, the stripper column pressure was set by controlling the amount of refrigerant going to the condenser. The reboiler heat input fixed the vapor rate. The column temperature was allowed. to. seek its own level. During stripping experiments; the 3-in. column was valved out of the system.

Once these independent variables were set, sufficient time was allowed for the entire system to reach "steady-state." Various tempëratures, pressures, liquid holdups, stream concentrations, and f $\mathrm{f}$ low rates were monitored during the experiments and were used to indicate when "steady-state" had been attained (i.e., no appreciable change in monitored variables for at least $2 \mathrm{hr}$ ). As the system approached steady-state operation, the various controllers were fine-tuned to alleviate any controller-induced oscillations. The wide variety of conditions studied caused this to be a time-consuming operation to the extent that:-controller fine-tuning became a major part of each experiment.

\section{MAS3 'LRANGTER DATA}

Experiments of this magnitude are, by nature, complex and necessitate certain englneering assumptions in the andysls of lle dald collected. : Although many of these assumptions are based on sound engineering principles, many are based on experience gained from operating the facility. For example, the composition analysis of the gàs streams ( $>1 \%$ light-gas content) were found to be more reliable "than the analysis of "the liquid streams ( $<1 \%$ light-gas content). The 
data analysis and the assumptions associated with it are discussed in detail in Appendix $\mathrm{C}$.

\subsection{Stripping Studies}

The primary function of the stripper column is to "strip" the krypton from the liquid $\mathrm{CO}_{2}$ and concentrate it in the column's off-gas. Consequently, all mass-transfer-related variables are based on krypton concentrations. A height of a transfer unit (HTU) is calculated based on resistance in the liquid phase using the following equations: 18

$$
\begin{aligned}
\text { HTU } & =z / N T U, \\
\text { NTU } & =\frac{x_{i}-x_{0}}{\left(x-x^{*}\right)_{l m}},
\end{aligned}
$$

and

$$
\left(x-x^{*}\right)_{\ell m}=\frac{\left(x_{0}-x_{0}^{*}\right)-\left(x_{i}-x_{i}^{*}\right)}{\ln \frac{x_{0}-x_{0}^{*}}{x_{i}-x_{i}^{*}}},
$$

where

$$
\begin{aligned}
Z & =\text { height of column packing, } f t, \\
\text { NTU } & =\text { number of transfer units, } \\
x_{i} & =\text { inlet liquid krypton concentration, } \\
x_{0} & =\text { outlet liquid krypton concentration. }
\end{aligned}
$$

The asterisk quantities denote concentrations in equilibrium with the adjacent phase. 
Two parameters, the column and overall decontamination factors, are calculated as a measure of the amount of krypton removed. The column decontamination factor $\left(D_{c}\right)$ is a measure of the column's efficiency, while the overall decontamination factor ( $D F_{0}$ ) indicates the efficiency of the column with its condenser and reboiler. Table 2 presents a summary of the stripping data.

Although six stripper experiments were conducted, only four exhibit a high degree of confidence. Two experiments (C4-206 and C4-214) were suspect due to poor counting statistics. In the analysis of stripper data, the measured-column-vapor-inlet-krypton concentration is of extreme importance becausc it is the basis for all material. ballances associated with the column. Thus the reliability of this sample is of the utmost necessity. A statistical analysis of the measured count rate proved to be the most convenicnt test of reliability. The standard deviation for any sample is defined as 19

$$
\sigma_{N}=\sqrt{\sigma_{c}^{2}+\sigma_{B}^{2}} \text {, }
$$

where

$$
\begin{aligned}
& \sigma_{N}=\text { standard deviation of the sample, } \\
& \sigma_{c}=\text { standard deviation of total number of counts registered, } \\
& \sigma_{\beta}=\text { standard deviation of the number of background counts } \\
& \quad \text { registered. }
\end{aligned}
$$

Statistical analysis indicates that there is a $99.7 \%$ probability that the true count rate lies within $\pm 3 \sigma_{N}$ of the measured count rate. ${ }^{19}$ 
Table 2. Stripping mass transfer data based on krypton concentrations

\begin{tabular}{|c|c|c|c|c|c|c|c|c|}
\hline $\begin{array}{c}\text { Experiment } \\
\text { No. }\end{array}$ & $\begin{array}{l}\text { Pressure } \\
\text { (psig). }\end{array}$ & $\begin{array}{c}\text { Average column } \\
\text { temperature } \\
\left({ }^{\circ} \mathrm{C}\right)\end{array}$ & $\begin{array}{l}\text { Pump rate } \\
\text { (gpm) }\end{array}$ & $\begin{array}{c}\mathrm{L} / \mathrm{V} \\
(\mathrm{mole} / \mathrm{mole})\end{array}$ & $\mathrm{VK} / \mathrm{L}$ & $\begin{array}{l}\text { HTU } \\
(f t)\end{array}$ & $\mathrm{DF}_{\mathrm{c}}$ & $\mathrm{DF}_{\mathrm{o}}$ \\
\hline$C 4-206$ & 250.2 & -22.6 & 0.415 & 7.8 & 1.33 & 0.42 & 397 & 1272 \\
\hline$C 4-214$ & 250.1 & -22.9 & 0.415 & 8.2 & $1: 27$ & 0.32 & 817 & 2873 \\
\hline$C 4-221$ & 250.0 & -22.5 & 0.415 & 8.8 & 1.18 & 0.27 & 1069 & 3529 \\
\hline$C 4-228$ & 250.0 & -22.3 & 0.415 & 8.9 & 1.18 & 0.21 & 1865 & 7127 \\
\hline$C 4-237$ & 250.0 & -22.7 & 0.415 & 8.6 & 1.22 & 0.28 & 832 & 2919 \\
\hline C4-244 & 249.7 & -22.8 & 0.415 & 9.5 & 1.10 & 0.38 & 41 & 124 \\
\hline
\end{tabular}


Thus a somewhat arbitrary decision was made to accept a sample whose count rate was such that the magnitude of $3 \sigma_{N}$ was $\leq 10 \%$ of the actual counts registered (see Table 3 ).

Figure 5 presents a graphic comparison between the two types of packing. The plot of HTU vs L/V indicates that under similar conditions HTU (PRO-PAK) $\leq$ HTU (Goodloe).

Table 4 presents a more detailed comparison between the 2-in.fractionator $\mathrm{HTU}$ and $\mathrm{DF}_{\mathrm{C}}$ and the 3-in.-stripper HTU and $\mathrm{DF}_{\mathrm{c}}$ (obtained in Campaign III). ${ }^{4}$ The 2-in.-fractionator HTU values are consistently lower than those for the 3-in. stripper. More importantly, the 2-in.fractionator $D_{c}$ values are consistently higher than the 3-in.-stripper data, indicating that the fractionator has more stages even though it is. shorter $(8.88 \mathrm{ft}$ vs $11.54 \mathrm{ft})$. These data indicate that the PROPAK packing has a lower HTU value than the Goodloe packing for stripping operations over the range of conditions studied.

\subsection{Fractionation Studies}

As stated earlier, the primary function of the fractionator is to remove light gases from the liquid. Consequently, its mass transfer parameters will be calculated using oxygen (the least volatile of the light gases of concern) concentrations. As with the stripping studies, the variables of interest are HTUs, $D F_{r} s$, and $D \bar{F}_{0} s$. Table 5 presents a summary of the fractionation mass transfer experiments.

No readily available comprehensive method exists to determine the acceptability of an experiment. Consequently, the analysis of the limited data available becomes more difficult. Experiments C4-171, 
Table 3. Statistical analysis of stripper vapor inlet ${ }^{85} \mathrm{Kr}$ concentration

\begin{tabular}{cccc}
\hline $\begin{array}{c}\text { Experiment } \\
\text { No. }\end{array}$ & $\begin{array}{c}\text { Standard deviation } \\
\text { (counts/min) }\end{array}$ & $\begin{array}{c}\text { Relative standard deviation } \\
(\%)\end{array}$ \\
\hline C4-206 & 7.02 & 5.0 \\
C4-214 & 3.92 & 6.6 & $\vdots$ \\
C4-221 & 3.33 & 3.2 & 1.0 \\
C4-228 & 4.07 & $\vdots$ & 0.8 \\
C4-237 & 6.30 & 0.2 & $\vdots$ \\
C4-244 & 24.90 & & $\vdots$ \\
\hline
\end{tabular}




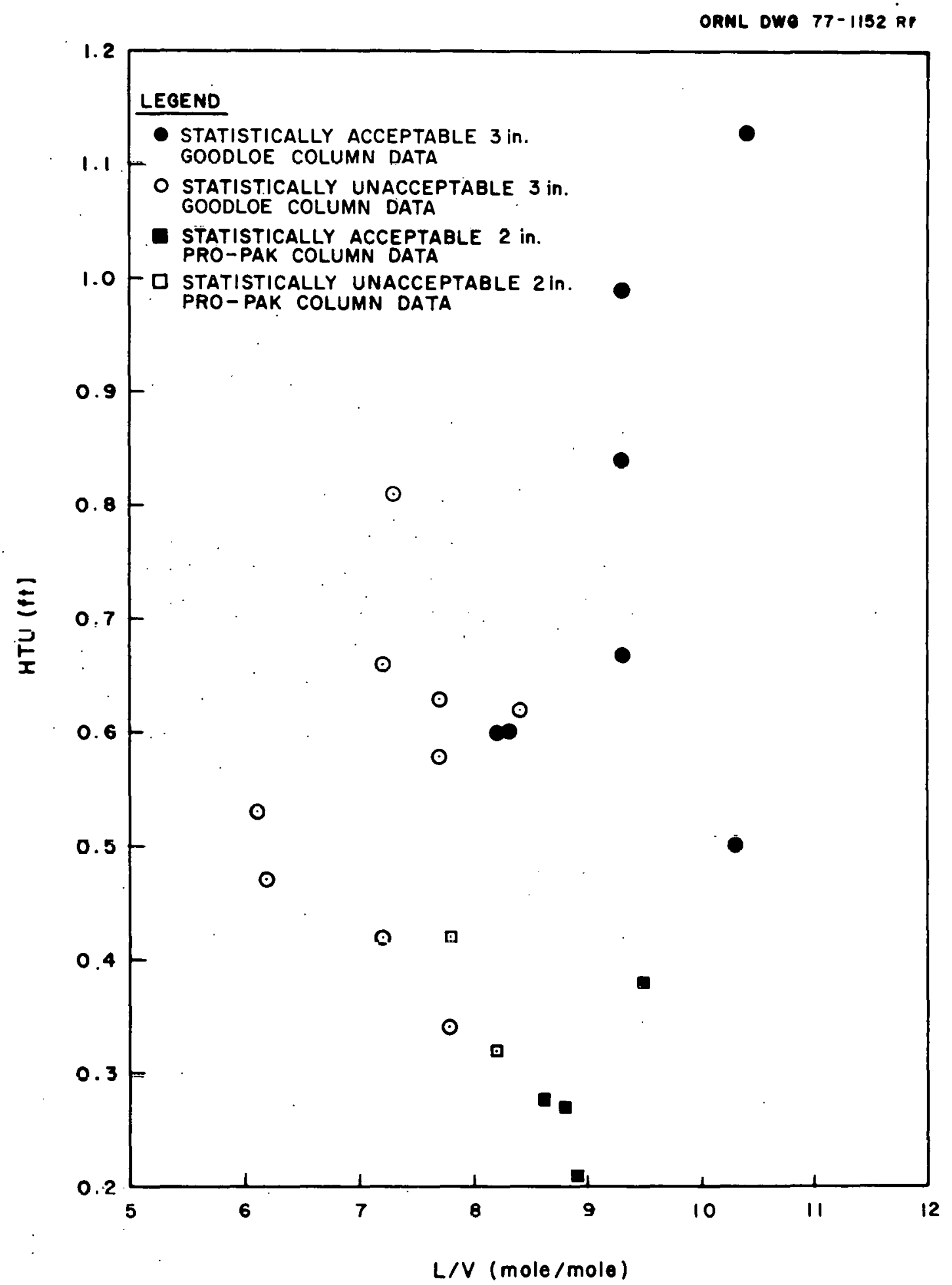

Fig. 5. Comparison of PRO-PAK and Goodloe stripping HTUs (based on krypton). 
Table 4. Comparison between PRO-PAK and Goodloe krypton stripping data

\begin{tabular}{ccccc}
\hline $\begin{array}{c}\text { Experiment } \\
\text { No. }\end{array}$ & $\begin{array}{c}\text { PRO-PAK column } \\
\text { HTU } \\
(\mathrm{ft})\end{array}$ & $\begin{array}{c}\text { Goodloe column } \\
\text { HTU } \\
(\mathrm{ft})\end{array}$ & $\begin{array}{c}\text { PRO-PAK column } \\
\text { DF }\end{array}$ & $\begin{array}{c}\text { Goodloe column } \\
\mathrm{DF}_{\mathrm{a}}^{\mathrm{a}}\end{array}$ \\
\hline $\mathrm{C} 4-221$ & 0.27 & 0.60 & 1069 & 50 \\
$\mathrm{C} 4-223$ & 0.21 & 0.59 & 1865 & 50 \\
$\mathrm{C} 4-237$ & 0.28 & 0.52 & 832 & 80 \\
$\mathrm{C} 4-244$ & 0.38 & 0.68 & 41 & 15 \\
\hline
\end{tabular}

$a_{\text {Taken from Campaign III data }}{ }^{4}$ at similar stripping factors. 
Takle 5. Fractionator mass transfer data based on oxygen concentrations

\begin{tabular}{|c|c|c|c|c|c|c|c|c|}
\hline $\begin{array}{c}\text { Experiment } \\
\text { No. }\end{array}$ & $\begin{array}{l}\text { Pressure } \\
\text { (psig) }\end{array}$ & $\begin{array}{c}\text { Avierage column } \\
\text { temperature } \\
\left({ }^{\circ} \mathrm{C}\right)\end{array}$ & $\begin{array}{c}\text { Pump rate } \\
\text { (gpm) }\end{array}$ & $\begin{array}{c}\mathrm{L} / \mathrm{V} \\
\text { (mole/mole) }\end{array}$ & $\mathrm{VK} / \mathrm{L}$ & $\begin{array}{l}\text { HTU } \\
(\mathrm{ft})\end{array}$ & ${ }^{D F}$ & $\mathrm{DF}_{\mathrm{o}}$ \\
\hline C4-171. & $2 \varepsilon 0.3$ & -20.8 & 0.5533 & 16.1 & 1.14 & 1.19 & 7 & 130 \\
\hline$C 4-181$ & 279.4 & -22.8 & 0.5533 & 15.5 & 1.22 & 0.94 & 13 & 45 \\
\hline C4-188. & 278.8 & -23.6 & 0.5533 & 15.7 & 1.19 & 2.40 & 4 & 15 \\
\hline C4-197 & $2 \varepsilon 0.0$ & -23.0 & 0.5533 & 15.3 & 1.22 & 1.33 & 8 & 20 \\
\hline$C 4-251$ & 279.7 & -20.2 & 0.4150 & 15.4 & 1.19 & 0.19 & 5468 & 18904 \\
\hline$C 4-259$ & 281.5 & -20.5 & .0 .4150 & 17.2 & 1.06 & 0.68 & 11 & 30 \\
\hline$C 4-266$ & 280.0 & -20.8 & 0.4150 & 17.0 & 1.08 & 0.59 & 15 & 47 \\
\hline
\end{tabular}


C4-181, C4-188, and C4-197 were 8-hr runs, and steady-state had apparently not been reached at the time of sampling. As with the Campaign III fractionation studies, the temperature of the fractionator column was continuously changing during each of the 8-hr operations. This, of course, indicates that the oxygen profile is also changing in the column. It should be noted that the determination of nonsteadystate experiments is greatly enhanced by a large population of experiments. Thịs is not the case here; thus it is conceivable, although unlikely, that further experiments would show that these four runs are within acceptable limits. For the purposes of this report, however, it will be assumed that they are unacceptable.

Experiments C4-251, C4-259, and C4-266 were 12-hr runs and showed a greater tendency toward maintaining constant readings for the various monitored variables, especially the fractionator column temperature. Figure 6 presents a comparison between the HTU values obtained for these three experiments using the 2-in. fractionator and those obtained using the 3-in. Goodloe column. As seen in the graph, experiments C4-259 and 44-266 appear to be comparable to the Goodloe data while experiment C4-251 does not. During the analysis of all experiments, the accuracy of the gas concentrations in the various streams is of the utmost importance. An off-gas material balance for experiment C4-251 gives a ${ }^{85} \mathrm{Kr}$ (the mnst reliably measured component) balance of 0.88 compared with 0.99 and 0.97 for experiments $44-259$ and C4-266, respectively (see Table C-7, Appendix C). Consequently, the analysis of experiment $44-251$ is suspect. Excluding experiment C4-251, the HTU 
ORNL DWG $77-1151$

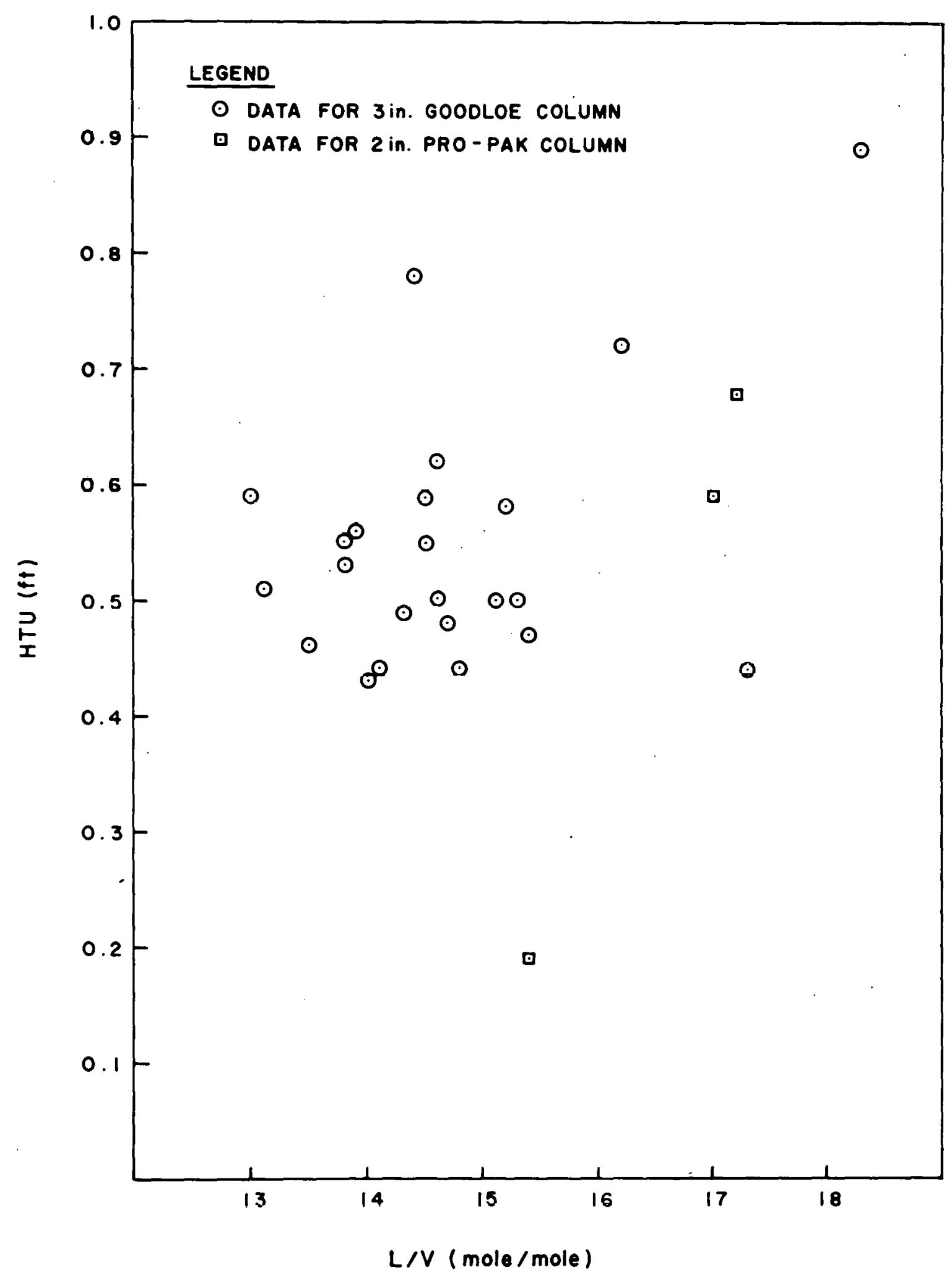

Fig. 6. Comparison of PRO-PAK and Goodloe fractionation HTUs (bascd on oxygen). 
values obtained for PRO-PAK appear to fall within the scatter of the Goodloe data, indicating that HTU (PRO-PAK) $\approx$ HTU (Goodloe).

\section{CONCLUSIONS AND RECOMMENDATIONS}

The installation of the third column (i.e., fractionator) in the KALC facility is complete. The facility now has the capability of being operated in a one-, two-, or three-column mode. Thus the facility is no longer restricted solely to individual column performance experiments but can be used to determine performance data for the overall system, making the facility more versatile and potentially more productive.

In previous campaigns, the Goodloe wire mesh packing used in the absorber and stripper columns had become distorted to the extent that the gas throughput of the two columns was reduced to $\sim 15 \%$ of that predicted by the manufacturer. The compressibility of the packing and the possible reduced throughput due to this compression has revealed the desirability of a random (i.e., noncompressible) packing with comparable throughput and mass transfer characteristics. Toward this end, the fractionator was filled with a new random packing known as PRO-PAK. Mass transfer and fluid dynamics data on the new packing have been collected.

Flooding experiments on the 2-in. fractionator with a $\mathrm{CO}_{2}$ system produced the following flooding curve for PRO-PAK packing: 


$$
\bar{y}=A+B(\bar{x})+C(\bar{x})^{2},
$$

where

$$
\begin{gathered}
\bar{y}=\log \left[\frac{U_{m}^{2} \rho_{G} \mu_{L}^{0.2}}{g \rho_{L}}\right], \\
\bar{x}=2.0+\log \left[\frac{L}{G} \sqrt{\rho_{G} / \rho_{L}}\right],
\end{gathered}
$$

$$
\begin{aligned}
A & =-2.738, \\
B & =-0.607, \\
C & =-0.118, \\
U_{m} & =\text { vapor velocity, } \mathrm{ft} / \mathrm{sec}, \\
\rho_{G} & =\text { vapor-phase density, } 1 \mathrm{~b} / \mathrm{ft}^{3}, \\
\mu_{L} & =\text { liquid-phase viscostty, } \mathrm{cP}, \\
g & =\text { constant, } 32.2 \mathrm{ft} / \mathrm{sec}^{2}, \\
\rho_{L} & =\text { liquid-phase density, } 1 \mathrm{~b} / \mathrm{ft}^{3}, \\
L & =\text { liquid rate, } 1 \mathrm{~b} / \mathrm{hr} \cdot \mathrm{ft}^{2}, \\
G & =\text { vapor rate, } 1 \mathrm{~b} / \mathrm{hr} \cdot \mathrm{ft}^{2} .
\end{aligned}
$$

The empirical flooding curve for PRO-PAK indicated that PRO-PAK has $60 \%$ the throughput capacity of Goodloe.

Experiments comparing the mass transfer characteristics of PROPAK and Goodloe packing during fractionation and stripping indicate that HTU (PRO-PAK) $\leq$ HTU (Goodloe), The pertinent operating variables and their ranges explored during the stripping mass transfer studies are the following: 


\section{$\underline{\text { Variable }}$}

Pressure, psig

Temperature, ${ }^{\circ} \mathrm{C}$

Liquid-to-vapor ratio, mole/mole $\underline{\text { Range }}$

$250 \pm 0.5$

$-22.5 \pm 0.4$

$7.8-9.5$

The pertinent operating variables and their ranges explored during the fractionation mass transfer studies are the following:

Variable

Pressure, psig

Temperature, ${ }^{\circ} \mathrm{C}$

Liquid-to-vapor ratio, mole/mole $\underline{\text { Range }}$

$280 \pm 2$

$-20.5--23.6$

$15.3-17.6$

It should be noted that the comparison between PRO-PAK and Goodloe mass transfer characteristics is a preliminary one. Consequently, some important operating variables related to mass transfer, such as pressure and pump rate, were varied only slightly or in some cases not at all in the interest of expediency. The limited PRO-PAK mass transfer data restricts the confidence of the comparison, however, the data does indicate that a more extensive campaign to quantify the mass transfer characteristics of PRO-PAK packing is warranted. 


\section{REFERENCF.S}

1. K. J. Notz, Selected Studies in HTGR Reprocessing Development, ORNL/TM-5328 (March 1976).

2. K. J. Notz, An Overview of HTGR Fuel Recycle, ORNL/TM-4747 (January 1976).

3. R. W. Glass et a1., Krypton Absorption in Liquid CO 2 (KALC) : Campaign. II in the Experimental Engineering Section Off-Gas Decontamination Facility, ORNL/TM-5095 (February 1976).

4. T. M. Gilliam, V. L. Fowler, and D. J. Inman, Krypton Absorption in Liquid $\mathrm{CO}_{2}$ (KALC): Campaign III in the Experimental Engineering Section Off-Gas Decontamination Facility, ORNL/'I'M-5655 (September 1977).

5. R. W. Glass et al., System Features and Component Descriptions for the Unit Operations Off-Gas Decontamination Facility, ORNL/TM4596 (February 1975).

6. Goodloe Information Buller1n No. 721, "How to Design a Goodloe Column."

7. R. W. Glass and H. W. R. Beaujean, "Preliminary Fluid Dynamics and Mass Transfer Performance of the Experimental Englneering Section Off-Gas Decontamination Facility Packed Columns," ĠC̄R: 74-27 (October 1974).

8. R. M. Canon, "A New Distillation Packing," Ind. and Eng. Chem. $\underline{41}$, 1953 (1949).

9. Scientific Development Co. Information Bulletin No. 12, "Distillat1on Packing and Columns." 
10. R. H. Perry and C. Chilton, Chemical Engineers Handbook, 5th ed. pp. 18-22, McGraw-Hill, New York, 1973.

11. Ibid., pp. 18-23.

12. J. S. Agala, B. W. Brian, and A. C. Sharon, Flooding and Mass Transfer in Goodloe Packed Columns, Part 2, ORNL/MIT-253 (April 1975).

13. W. D. Burch et al., LMFBR Fuel Recycle Program Progress Report for Period April 1 to December 31, 1974, ORNL/TM-4836 (April 1975).

14. R. C. Weast, S. M. Selby, and C. D. Hodgman, Handbook of Chemistry and Physics, 45th ed., pp. F16-21, The Chemical Rubber Co., Cleveland, Ohio, 1964.

15. Du Pont Information Bulletin No. T-12, "Thermodynamic Properties of Freon-12 Refrigerant."

16. C. L. Yaws, K. H. Li, and C. H. Kuo, "Carbon Oxides: CO and $\mathrm{CO}_{2}$," Chem. Eng. 81, 115-21 (September 30, 1974).

17. W. M. Newton et al., "How Surface Tension Affects Flooding in Packed Columns," Pet. Refiner 31(10), 141-43 (October 1952).

18. R. E. Treyba1, Mass Transfer Operations, 2nd ed. pp. 250-53, McGraw-Hill, New York, 1968.

19. J. H. Harley and S. E. Wiberley, Instrumental Analysis, p. 369, Wiley, New York, 1954. 
THIS PAGE

\section{WAS INTENTIONALLY LEFT BLANK}


APPENDIXES 
THIS PAGE

WAS INTENTIONALLY

LEFT BLANK 
APPENDIX A: DETAILED COMPONENT DESCRIPTION

\section{A.1 Fractionator Column}

The fractionator column (see Fig. A-1) is installed in the EES-ODF facility in such a manner that it may be operated alone for specific tests, as a second column for stripping or fractionation studies, or as a fractionation column in a three-column system (see Fig. A-2). In this latter mode, liquid effluent from the absorber level tank enters the top of the fractionation column, where the light gases are removed through the condenser. The liquid, now containing essentially only ${ }^{85} \mathrm{Kr}$, leaves the column via the reboiler to be fed to the stripper column.

The fractionator column is constructed of three 35-3/4-in.-long segments of 2 -in. sched-40 pipe connected by expanded sections (surrounding each column segment). Each expanded section is composed of a 3 -in. by 2-in. sched-40 reducer and a 3-1/16-in.-diam sample station (machined from bar stock) for gas and liquid sampling. In addition to sample lines and a fitting for a thermocouple and pressure tap, each expanded section contains a 1/2-in. sched-40 pipe welded through the shoulder of the reducer for solvent inlet.

The three-column segments are packed to a total height of $8.88 \mathrm{ft}$ with commercially available PRO-PAK packing. * Each packed segment contains (1) two thermocouple taps equally spaced along the section, and (2) two pressure taps located $180^{\circ}$ from the thermocouple taps. The process volume within the rectification column is $00.25 \mathrm{ft}^{3}$.

\footnotetext{
${ }^{*}$ A product of the Scientific Development Company, State College, Pa.
} 


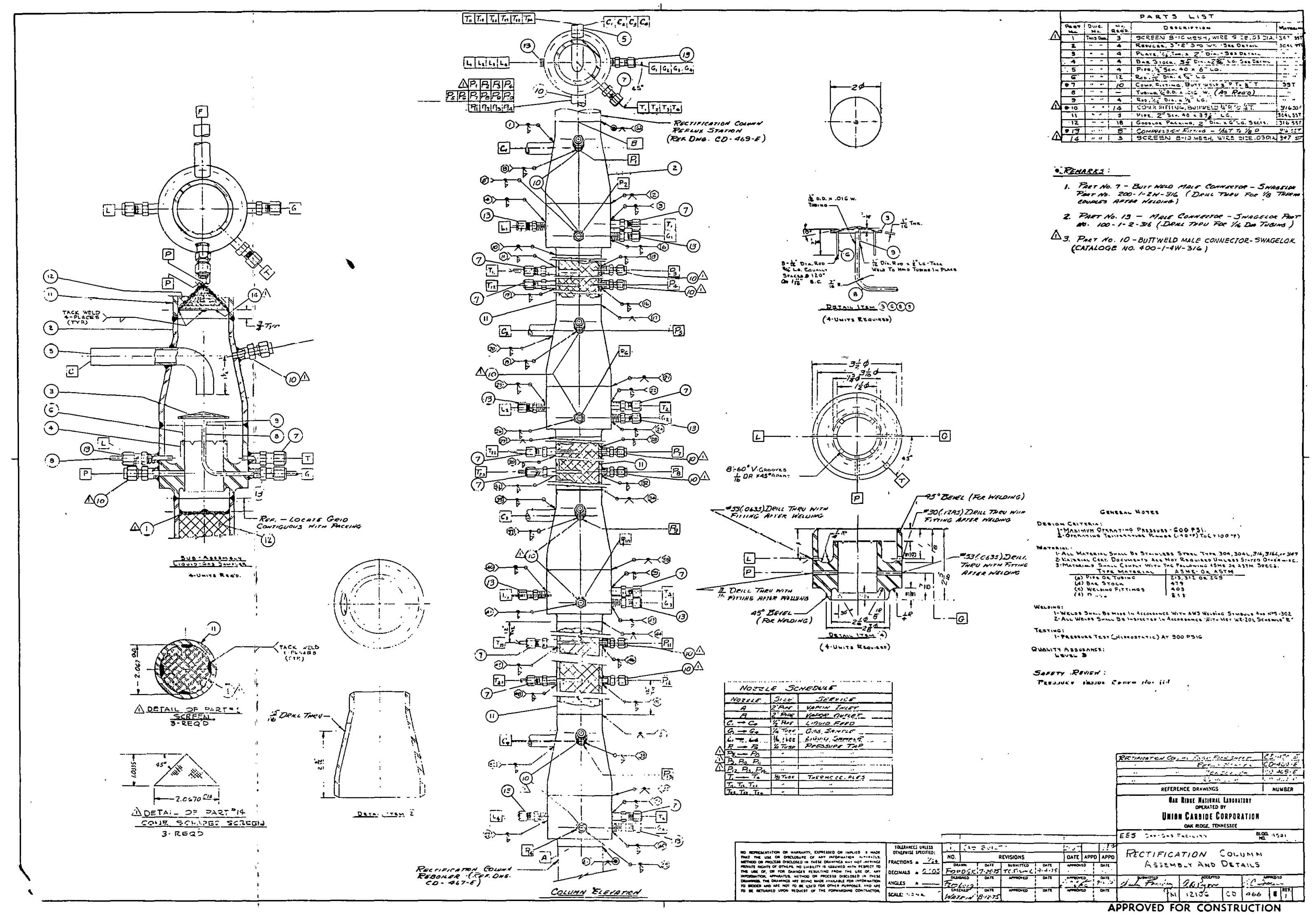

Fig. $\Lambda-1$. Detailed engineering drawing of fractionator column. 


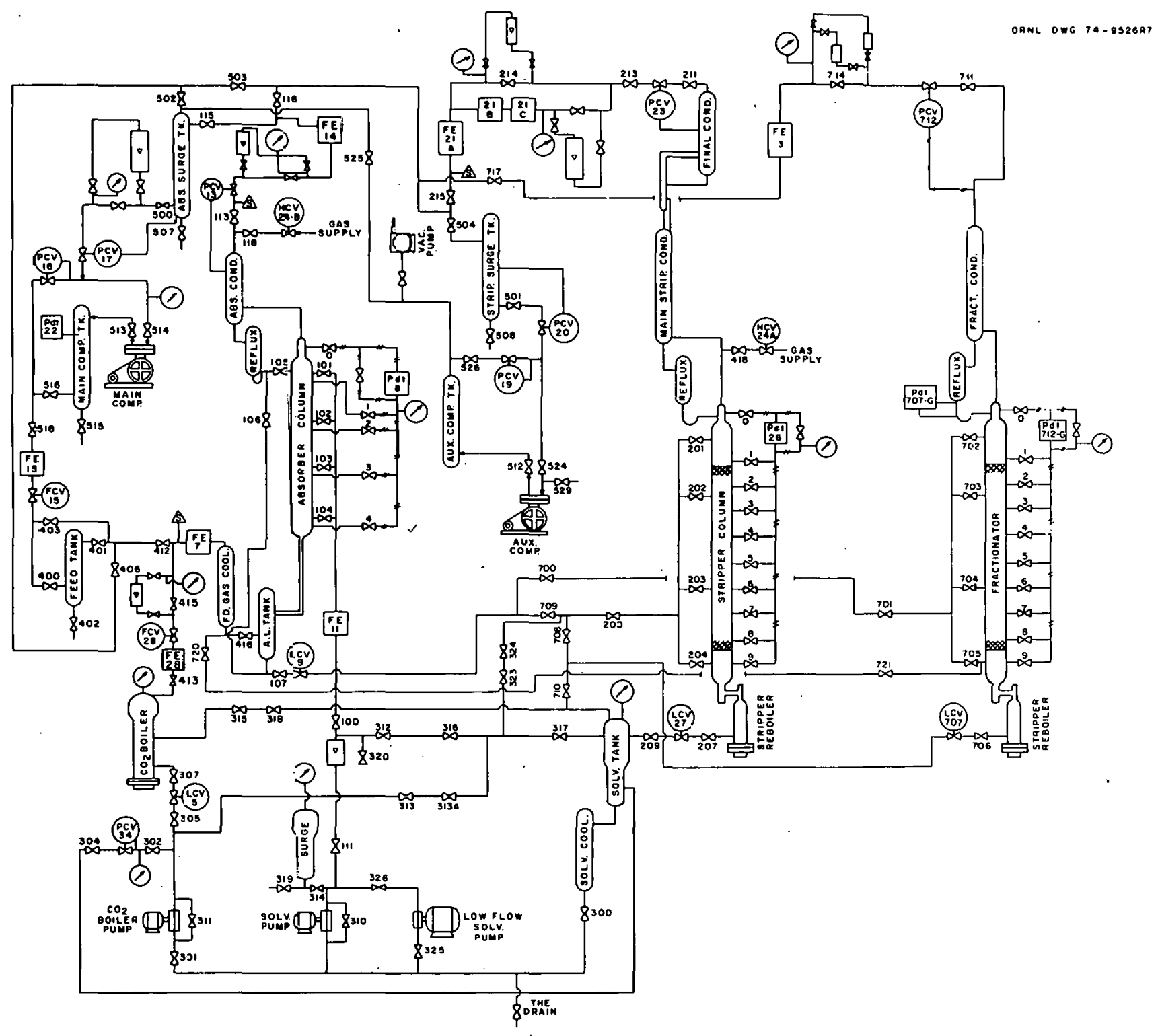

Fig. A-2. The Experimental Engineering Section Off-Gas

Decontamination KALC Facility. 
The column is designed for service at pressures up to 600 psig at temperatures from -40 to $+100^{\circ} \mathrm{F}$ and has been hydrostatically pressuretested at 900 psig. The off-gas line is provided with a 1-in. 550-psig (nominal) rupture disc and a 1-in. 600-psig (nominal) relief valve.

\section{A.2 Fractionator Reboiler}

Vapor flow in the fractionator column is provided by vaporization of part of the column liquid bottoms in the reboiler (see Fig. A-3). The unvaporized portion of the liquid bottoms passes from the reboiler to the stripper column (during three-column operations) or to the solvent tank (in one- or two-column operations). The reboiler has a rated heating capacity of $5 \mathrm{~kW}$ (electrical immersion heater, General Electric No. 20612) and a process volume of $20.31 \mathrm{ft}^{3}$.

The reboiler is welded directly to the bottom of the fractionator column. Two $3-i n$, sched-40 tees with 23 in. of 3 -in. sched-40 connecting the branches form an " $\mathrm{H}$ " as the uppermost portion of the reboiler. One tee is welded to a $3-i n$. by $2-i n$. sched -40 concentric reducer which is welded to the fractionator column and forms the upper part of a 1iquid level reservoir ( 8 in. of 3 -in. sched -40 pipe welds to the other end of the tee and is fitted for a liquid level probe). Thermocouple taps are provided in the capped upper end of the sccond tee which connecies to the 3-in. sched-40 reboiler shell proper. 'I'he 3-in. shell houses the immersion heater, which is flanged through the lower end of the she11. Liquid drains from the fractionator column into the level 


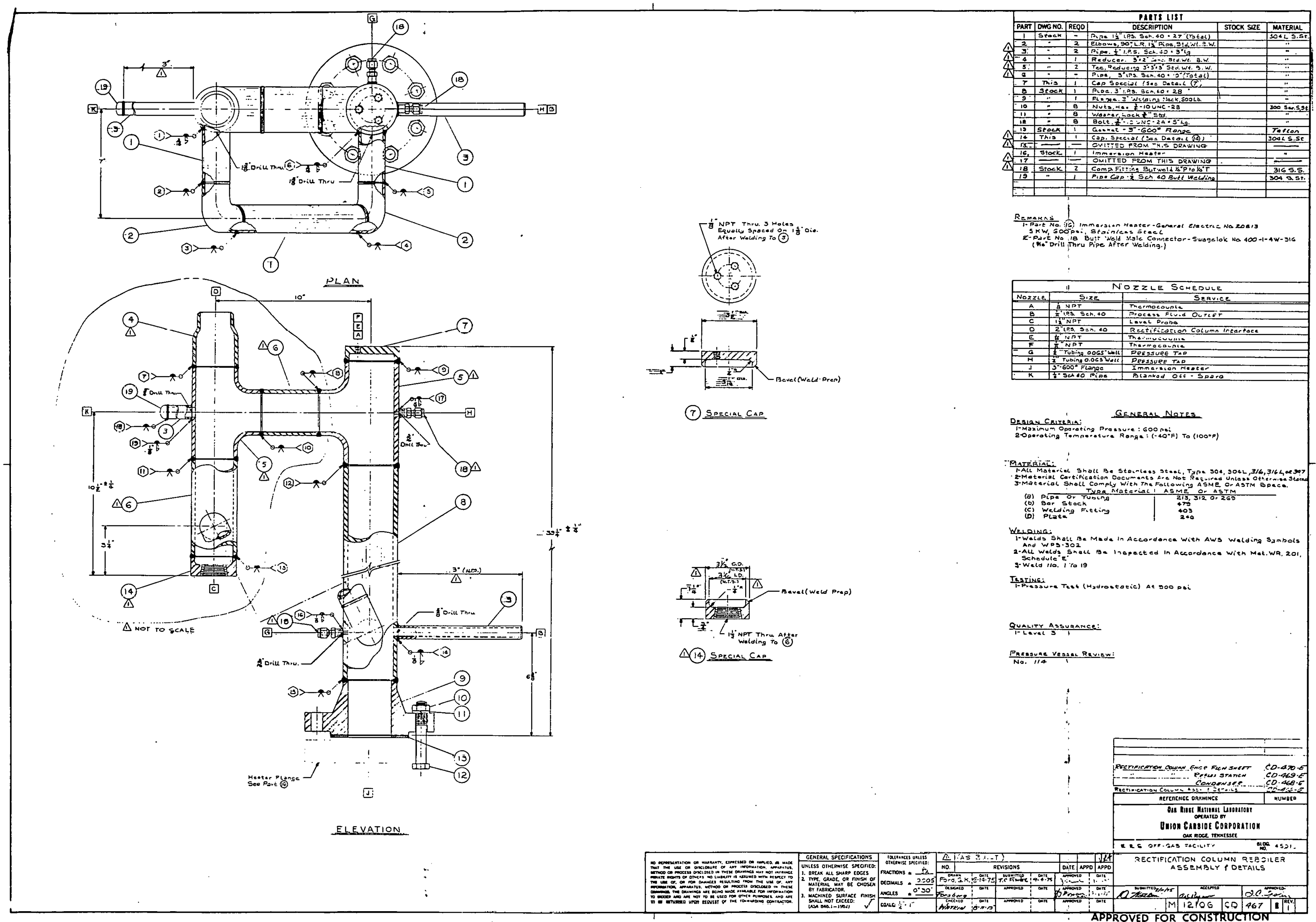

Fig. A-3. Detailed engineering drawing of fractionator column reboiler. 
reservoir, and finally into the lower part of the heater shell through a $1-1 / 2-i n$. sched-40 pipe.

Liquid from the fractionator column and vapor to the column pass through the "H" arrangement; during operations, the liquid level is maintained at approximately the weld junction of the reboiler shell and the 3-in. tee (to ensure that the heaters are totally immersed). Liquid from the lower section exits through a 1/2-in. sched-40 pipe in the sidewal1 6 in. above the bottom flange.

The reboiler is designed for operation up to 600 psig over a temperature range of $-40^{\circ}$ to $100^{\circ} \mathrm{T}$. The rebuiler has been hydrostatically pressure tested at 900 psig.

\section{A.3 Fractionator Column Reflux Station}

Liquid reflux from the fractionator column condenser to the top of the coluinm may be munficored chrough the fractionator column reflux station (see Fig. A-4). Vapor from the top of the column passes to the condenser, contacting the returning liquid only immediately above the column proper: The reflix iale is delermlued by the pressire drop produced diruss an orffice arrangement in the reflux return line, which is monitored with a 0-10 in. $\mathrm{H}_{2} 0$-pressure transmitter.

The reflux station consists of 89 in. of $1 / 2-i n$. sched-40 pipe. Liquid enters thromgh a 1/2-in. sched-10 nozzlc ncor the ton of the unit and exits through the 3/4-in. $x$ 0.065-1n. wall orifice loop in the bottom, returning to the column extension p1ping. Pressure above the liquid in the station is equalized with the column pressure through a 1/2-in. line near the top of the column extension piping. 


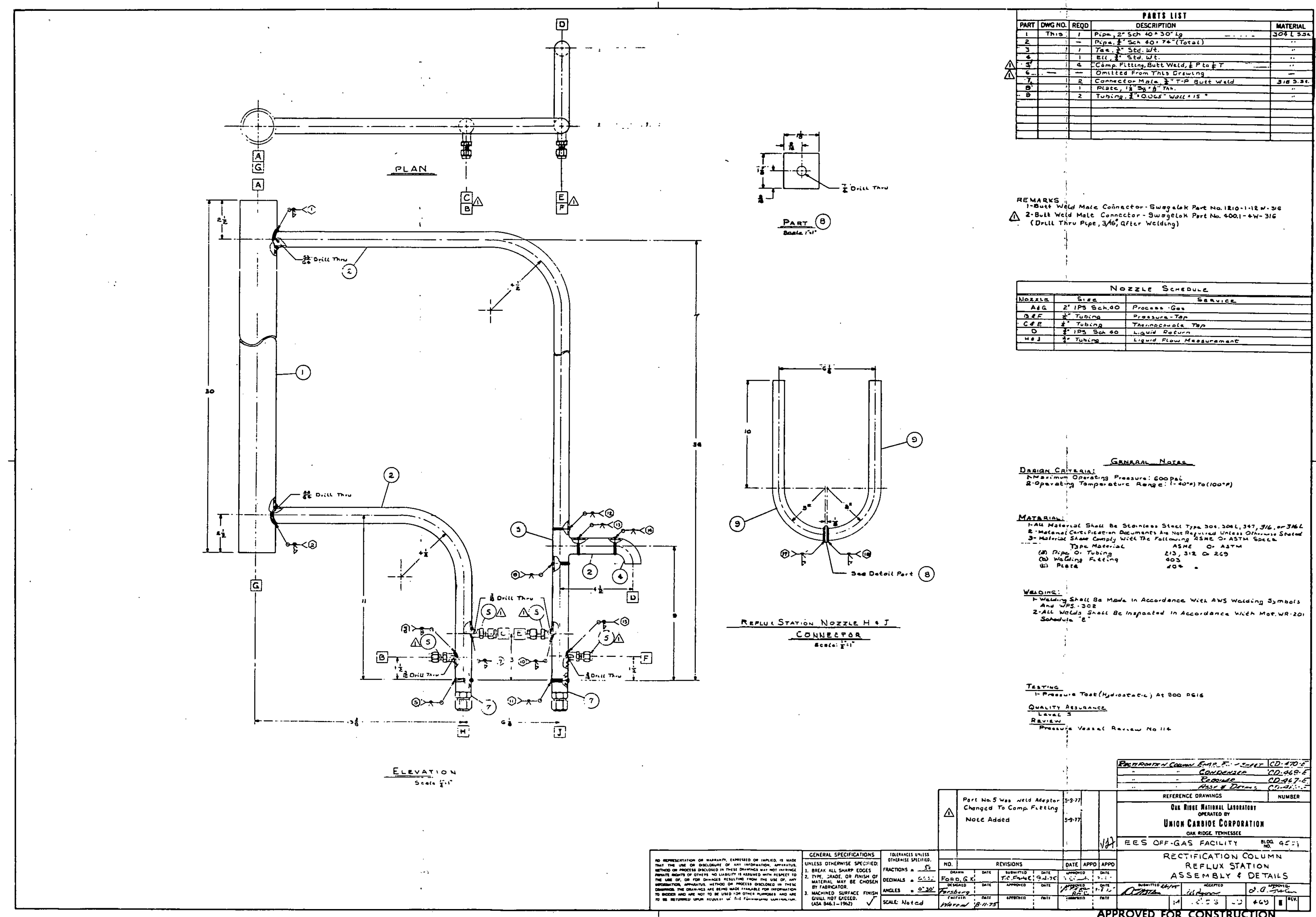

Fig. A-4. Detailed engineering drawing of the fractionator column 
The process volume for the station, including the orifice arrange-: ment, is $\sim 0.01 \mathrm{ft}^{3}$. The unit is designed to operate at pressures up to 600 psig and at temperatures ranging from -40 to $+100^{\circ} \mathrm{F}$ and has been hydrostatically pressure tested at 900 psig.

\section{A.4 Fractionator Column Condenser}

A portion of the overhead vapor from the fractionator column is condensed in the fracliunatur condenser (see Fig. A-5) and returned via the reflux station to the top of the column. The remaining vapor passes from the condenser to a surge tank where it may be used as recycle gas.

The unit consists of a 54-in. length of 8 -in. sched-40 pipe as the outer shell. A 54-in. length of 6-in. sched-80 pipe is used as an inner she1.1 to reduce volume and is wound with $\sim 110 \mathrm{ft}$ ( 2 coils) of 1/2-in.-UD by U.065-in. wall-tubing. The two shells are welded together at each end using 8-5/8-in.-OD by 6-5/8-in.-ID by 1-in.-thick plates . These plates are provided with nozzles for process gas and liquid outlels (sliell slet) and for refrlgcrant linlet and outlet (tube side). Hittings are also provided for thermocouples. The gas inlet nozzle from the column proper is a $2-i n$. by 8 -in. sched-40 pipe welded into the side of the outer shell $3 \mathrm{in.}$ from the bottom of the condenser. The process volume ic $0.47 \mathrm{ft}^{3}$. The anticipated conling eapacity is $12,000 \mathrm{Btu} / \mathrm{hr}$ at $-40^{\circ} \mathrm{F}$.

The fractionator condenser is designed to operate at pressures up to $600 \mathrm{psig}$ at temperatures from -40 to $100^{\circ} \mathrm{F}$. The vessel has been hydrostatically pressure tested at 900 psig shell side with 0 psig tube side and 450 psig tube side with 0 psig shell side. 

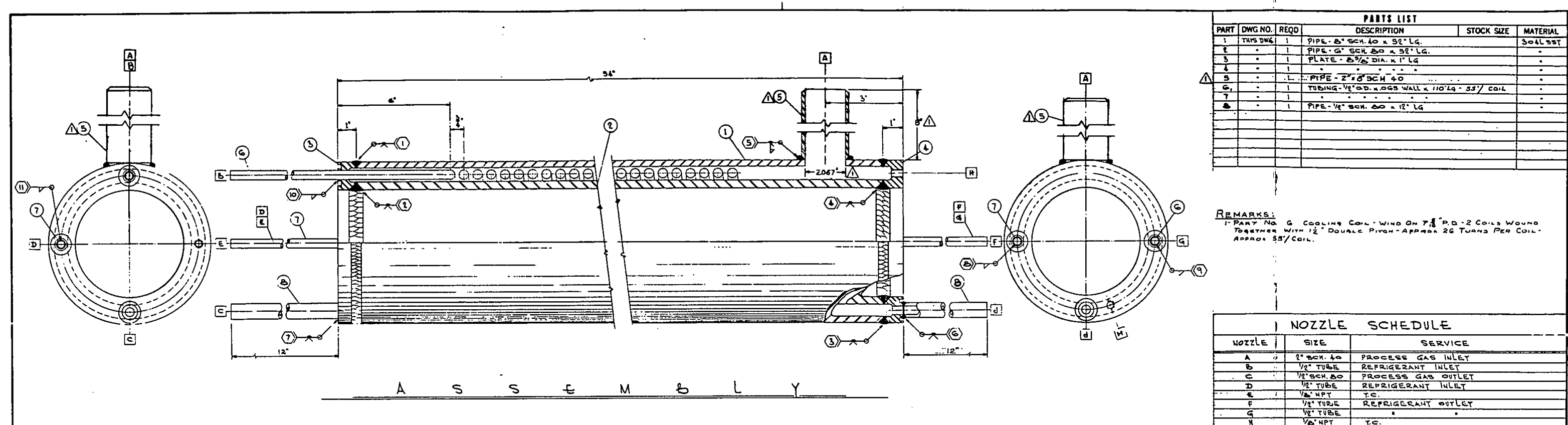

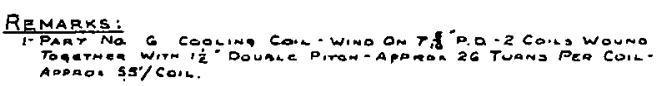

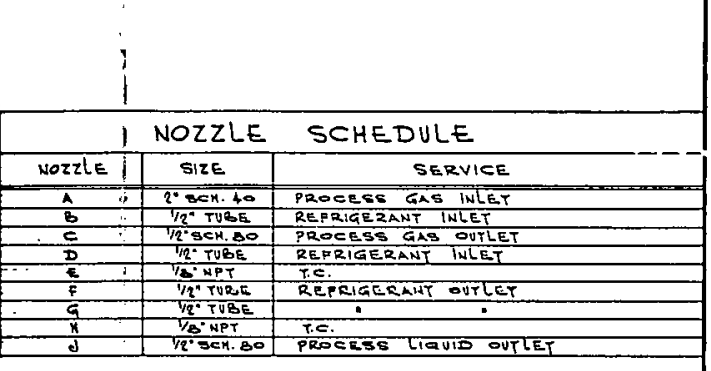

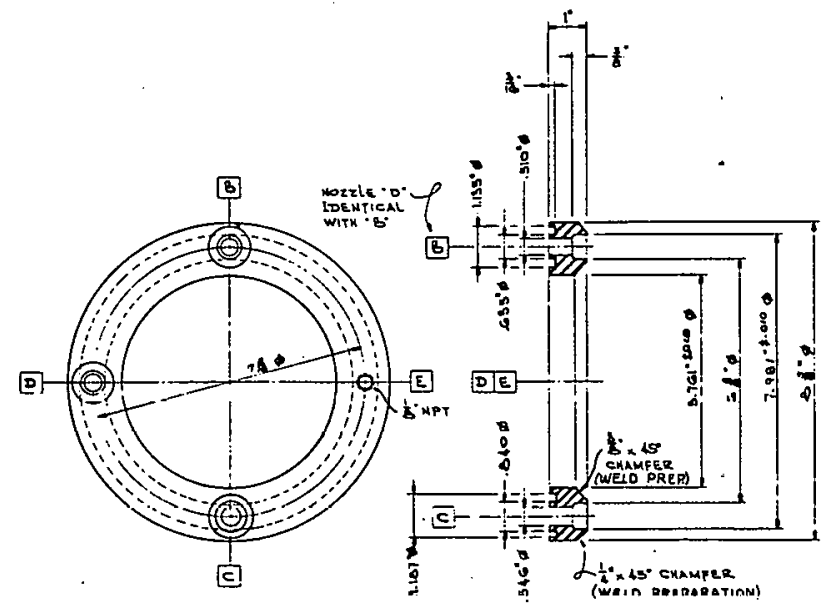

DETAIL PART (3)

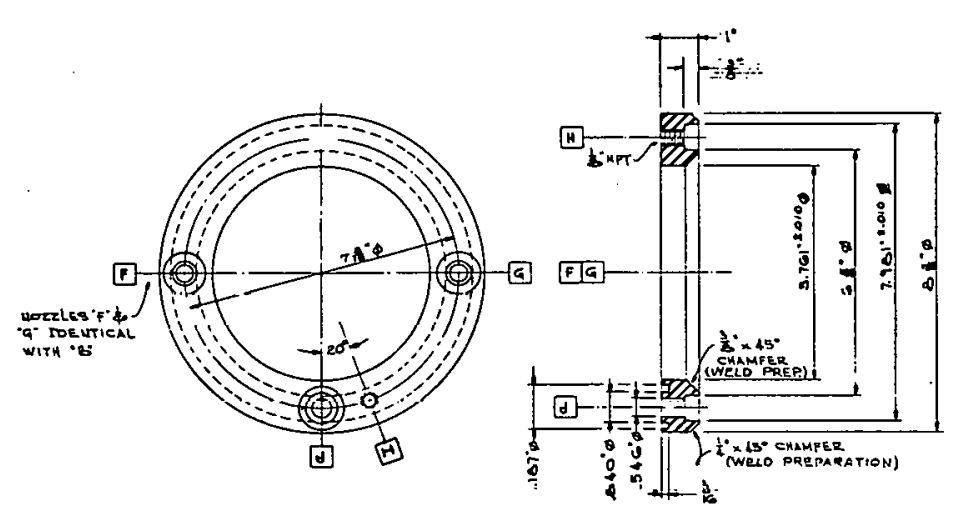

DETAIL PART (4)
NOTES:

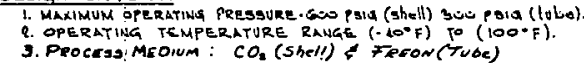

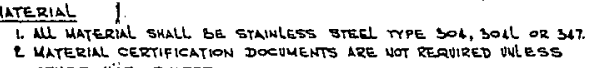

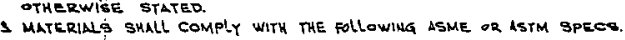

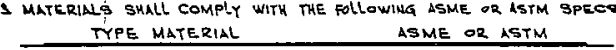
(c) pipe or Tubing (b) BAR STROE
(c) WeLDing FiTtings
(d) PLATE

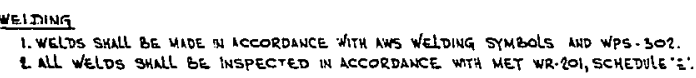
TESTina

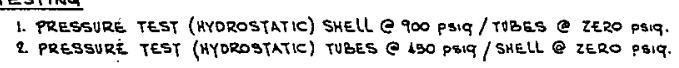
QuDLITY ASSURANCE

$\frac{\text { PRESSURE VESSEL REVIEW }}{\text { No. } 147}$

No. 147

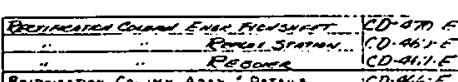

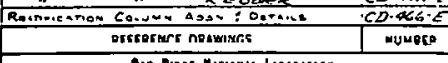

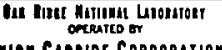

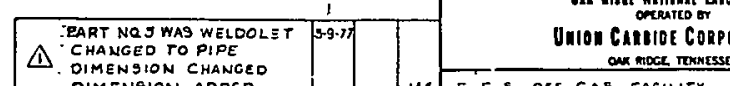

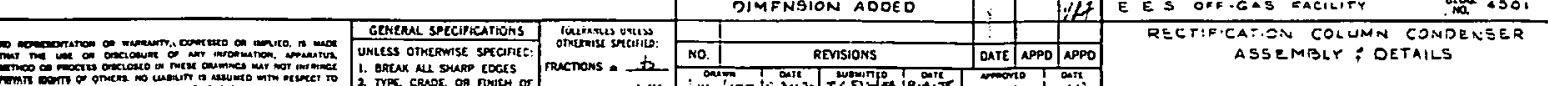
7ry

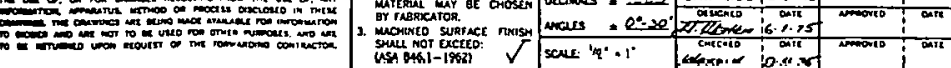

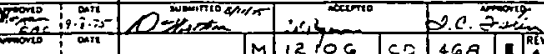

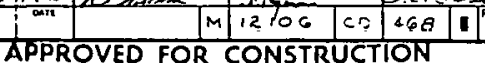




\section{A.5 Refrigeration}

Refrigeration for the fractionator condenser is provided by a unit purchased from Tenney Engineering, Inc. (Tenney Job No. 8737). This unit (designated as Unit C) consists of a Copeland No. MRA-2-0500-TFD460/3/60 compressor assembled with necessary operating and safety hardware as shown on Tenney Dwg.-8737-20-3. It is water-cooled and delivers $-10,000 \mathrm{Btu} / \mathrm{hr}$ at $-40^{\circ} \mathrm{C}$ through the evaporation and condensation of $\mathrm{R}-502$ (an azeotropic mixture of $\mathrm{R}-22$ and $\mathrm{R}-115$ ).

\section{A. 6 Process Instrumentation and Controls}

Installed in the system are 27 copper constantan thermocouples that are constantly monitored with 12-pt. temperature recorders. Fifteen of these thermocouples have been calibrated to $\pm 0.1^{\circ} \mathrm{C}$ and can be monitored individually with a Leeds and Northrup, Type K-3 Universal Potentiometer (see 'l'able A-1).

The level element for the roboiler ie a lí-in. capacitance-type probe (Drexelbrook Model 508, Drexelbrook Eng. Co., Horsham, Penn.), electrically connected to a level indicating transmitter (Drexelbrook Model 408-1000) that has an output of 4 to $20 \mathrm{~mA} \mathrm{dc}$. This electrical signal is then converted to a 3-15 psi output through use of an electrical-pneumatic transducer (Conoflow Model 'l'-25, Conoflow Corp. Blackwood, N.J.). Thin pncumntic aignnl ia then nafed hy a preumatie controller (three-mode Foxboro Model 48P4, the Foxboro Co., Foxboro, Mass.) to operate the level control valve. This valve (Research Controls, Tulsa, Okla.) is pneumatically operated (3-15 psi) and has a 1/2-in. 316 SST body which contains an equal percentage "trim" $\left(\mathrm{C}_{\mathrm{V}}=0.8\right)$ and 
Table A-1. Thermocouple listing

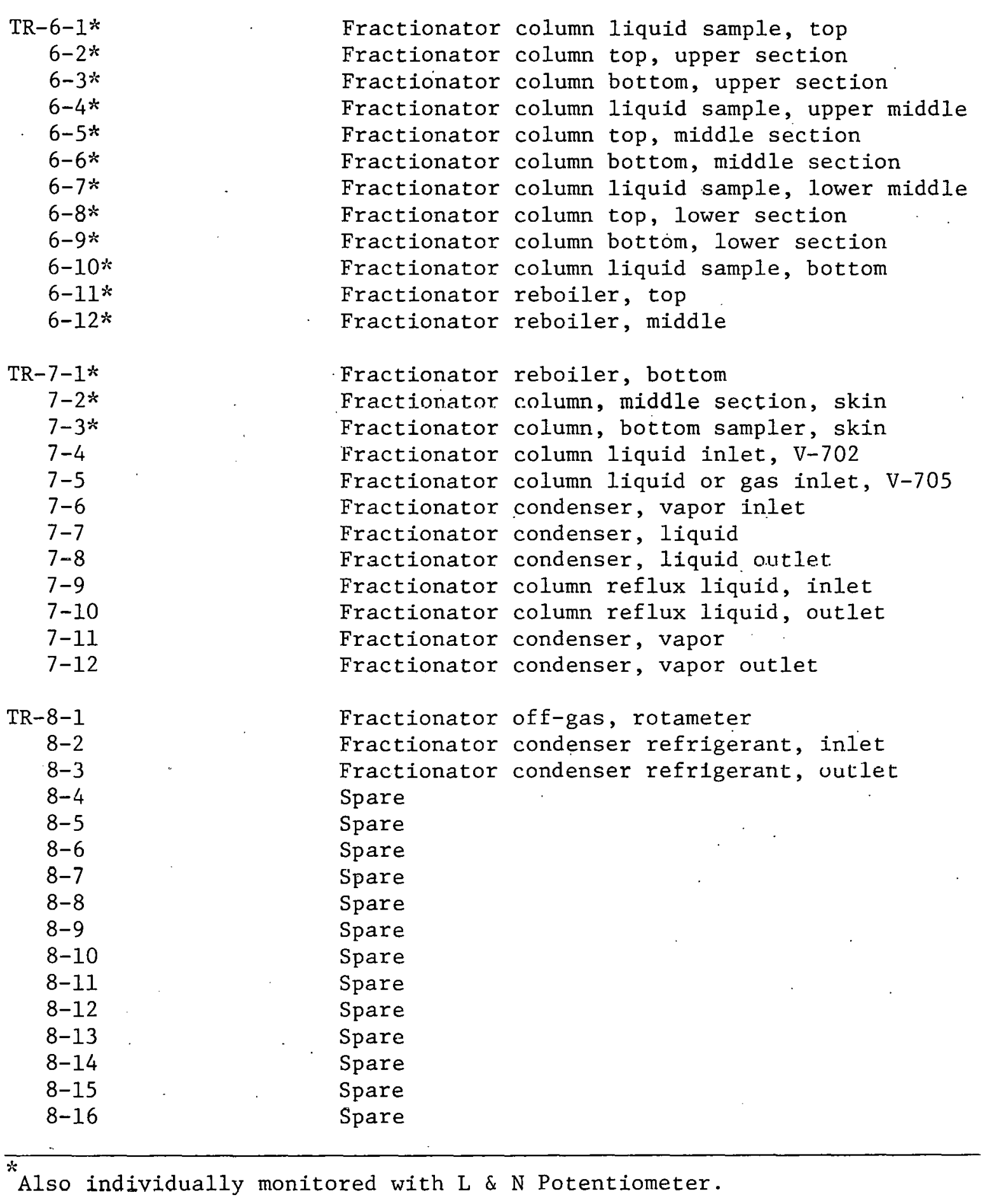


a Teflon-packed stem. This valve also contains an integral positioner and is of the air-to-close type.

The off-gas control valve is the same type as the level control valve but contains a "trim" of $C_{V}=0.08$. "This valve also uses a Foxboro pneumatic controller for operation. Automatic mode controls system pressure via process gas flow rate (with refrigeration control on manual) or manual mode for constant off-gas rate (with refrigeration controller on automatic for pressure control).

The off-gas flow rate is measured with a $F \& P$ tube-type rotameter (F \& P Model 10A1735, Fisher and Porter Co., Warminster, Pa.) calibrated at the Y-12 Standards Laboratory.

Refrigeration control is also provided by a Foxboro pneumatic controller and an Evaporator Pressure Control valve (EPR-12, 1/2-in. nominal port size; Alco Controls, St. Louis, Mo.) that can be operated in the automatic or manual mode for the purpose described above.

The electrical system for the reboiler immersion heater consists of three "stacked" motor-driven variacs (type 12560, The Superior Electric Co., Bristol, Conn.), with an input of $360 \mathrm{~V}$, and an output of 0 to $480 \mathrm{~V}$ and $28 \mathrm{~A}$. The voltage and amperage are measured with two digital multimeters (Data Precision Model 245, Data Precision Corp., Wakefield, Mass.) using $4: 1$ potential transformers and $6: 1$ current transformers (field mounted). so that no more than 120 volts is ever seen in the control room.

One. Tigerman "Tele-Alarm" Annunciator (Tigerman Eng. Co., Chicago, I11.) is employed in the control room to indicate component abnormalities during operations (see Table A-2). 
Table A-2. Control-panel alarms (Panel 5)

\begin{tabular}{cl}
\hline Position & \multicolumn{1}{c}{ Description } \\
$5-1$ & Refrigeration unit "C" out \\
$5-2$ & Fractionator reboiler lo-level \\
$5-3$ & Fractionator reboiler hi-temperature \\
$5-4$ & Fractionator column hi-pressure \\
$5-5$ & Spare \\
$5-6$ & Facility exhaust fans off \\
\hline
\end{tabular}


Other related system features and components necessary for operation of the fractionator column have been described previously. ${ }^{1}$

\section{A.7 Process Monitoring and Sampling}

Krypton-85 and oxygen are continuously monitored in the rectification column off-gas stream. The ${ }^{85} \mathrm{Kr}$ is detected by a beta scintillation detector and the count rate is recorded on a strip chart recorder. A M-S-A Magnetic Oxygen Analyzer Model 802 (Mine Safety Appliances, Pittsburg, $\mathrm{Pa}$. ) is used to measure the oxygen concentration. This analyzer is a paramagnetic wind type oxygen analyzer. The output from the analyzer is recorded on a strip chart recorder. Both krypton and oxygen monitors are used to indicate steady-state operations.

Samples may be taken from eight internal points of the column, the off-gas stream, and the reboiler liquid stream. The samplers are piped to the central sampling station where they can be analyzed for ${ }^{85} \mathrm{Kr}$ and light-gas compositions. 2,3

\section{A.8 References for Appendix A}

1. R. W. Glass et a1., System Features and Component Descriptions for the Unit Operations Off-Gas Decontamination Facility, ORNL/TM-4596 (February 1975).

2. D. M. Levins et al., Monitoring and Analysis of Process Streams in a $\mathrm{Kr}-85$ Off-Gas Decontamination System, ORNL/TM-4923 (July 1975).

3. D. J. Inman, Component Analysis of the Experimental Engineering Section Off-Gas Decontamination System, ORNL/GCR-77/21 (in preparation). 


\section{APPENDIX B: FLOODING EXPERIMENTS}

\section{B.1 Flooding Point Determination}

The fractionator flooding studies were performed with saturated $\mathrm{CO}_{2}$. The fractionator column was operated in total reflux (i.e., no off-gas); thus the vapor rate (V) in the column was determined by the boilup rate in the reboiler:

$$
\mathrm{V}=(\mathrm{KW})(\mathrm{B}) \text {, }
$$

where

$$
\begin{aligned}
\mathrm{KW}= & \text { reboiler heat input, } \mathrm{KW}, \\
\mathrm{B}= & \text { conversion factor at reboiler temperature (nominally } \\
& 4.2 \mathrm{scfm} / \mathrm{kW}) .
\end{aligned}
$$

The liquid rate then becomes a function of pump rate and boilup:

$$
L=(G P M) A+(k W)(B)
$$

where

$$
\begin{aligned}
\mathrm{GPM}= & \text { pump rate, gal } / \mathrm{min}, \\
\mathrm{A}= & \text { conversion factor at the pump suction temperature } \\
& \quad \text { (nominally } 77.0 \mathrm{scfm} / \mathrm{gpm})
\end{aligned}
$$

The fractionator column was considered to be flooded when the pressure drop across the column became greater than 10 in. $\mathrm{H}_{2} \mathrm{O}$. The flooding points were obtained by increasing the boilup rate, at a fixed pump rate, unt1l the desired pressure drop across the column was obtained. The pressure taps are shown in Appendix A, Fig. A-1. 
A summary of the flooding experiments are shown in Table B-1.

Flooding points are usually obtained by plotting the log of the pressure drop vs the log of the gas velocity at a constant liquid velocity. ${ }^{1}$ The flooding point is then determined as the point at which the pressure drop increases rapidly for a very small change in the gas velocity (or more practically, the point at which the curve undergoes a second slope change). The reliability of this method is greatly reduced by a small number of data points and a lack of visual confirmation of flooding. Consequently, a more convenient method of presenting the flooding point is to use a modified Sherwood, Shipley, and Holloway correlation. ${ }^{2}$ The data are presented (see Fig. B-1) as a plot of

$$
\frac{U_{m}^{2} \rho_{G} \mu_{L}^{0.2}}{g \rho_{L}} \text { (as the ordinate value) }
$$

vs

$$
\frac{L}{G} \sqrt{\rho_{G} / \rho_{L}} \text { (as the abscissa value), }
$$

where

$$
\begin{aligned}
& U_{m}=\text { vapor velocity, } \mathrm{ft} / \mathrm{sec}, \\
& \rho_{G} \text { - vapor-phasc denoity, } 1 \mathrm{~b} / \mathrm{ft}^{3}, \\
& \mu_{T^{\prime}}=1 \text { iquid-phase viscosity, } \mathrm{eP} \\
& g \text { - cunstant, } 32.2 \mathrm{ft} / \mathrm{sec}^{2}, \\
& \rho_{L}=1 \text { iquid=phase density, } 1 \mathrm{~b} / \mathrm{ft}^{3}, \\
& L=1 \text { iquid rate, } 1 \mathrm{~b} / \mathrm{hr} \cdot \mathrm{ft}^{2}, \\
& G=\text { vapor rate, } 1 \mathrm{~b} / \mathrm{hr}^{2} \mathrm{ft}^{2} .
\end{aligned}
$$


Table B-1. Summary of flooding data

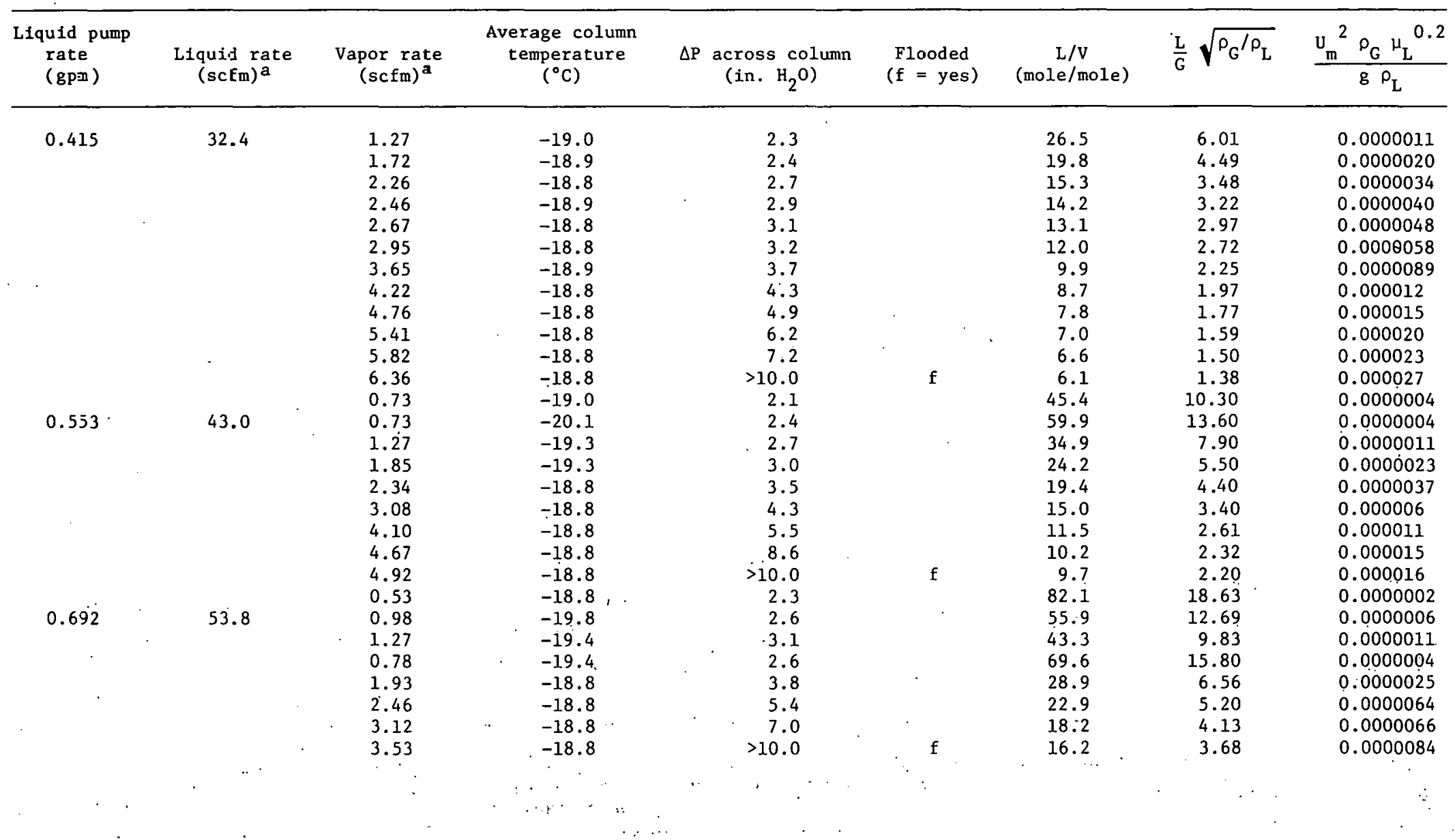


Table B-1 (ccnt'd)

\begin{tabular}{|c|c|c|c|c|c|c|c|c|c|}
\hline $\begin{array}{l}\text { Liquid pump } \\
\text { rate } \\
\text { (gpm) }\end{array}$ & $\begin{array}{l}\text { Liquid rate } \\
(\operatorname{scfm})^{a}\end{array}$ & $\begin{array}{l}\text { Vapor rate } \\
\quad(\mathrm{scfm})^{a}\end{array}$ & $\begin{array}{l}\text { Average column } \\
\text { temperature } \\
\left({ }^{\circ} \mathrm{C}\right)\end{array}$ & $\Delta \mathrm{P}$ & $\begin{array}{l}\text { across column } \\
\left(\text { in. } \mathrm{H}_{2} \mathrm{O}\right)\end{array}$ & $\begin{array}{l}\text { Flooded } \\
(\mathrm{f}=\text { yes })\end{array}$ & $\begin{array}{c}\mathrm{L} / \mathrm{V} \\
\text { (mole/mole) }\end{array}$ & $\frac{L}{G} \sqrt{\rho_{G} / \rho_{L}}$ & $\frac{\mathrm{U}_{\mathrm{m}}^{2} \rho_{\mathrm{G}} \mu_{\mathrm{L}}^{0.2}}{\mathrm{~g} \rho_{\mathrm{L}}}$ \\
\hline \multirow[t]{4}{*}{0.692} & 53.5 & 2.67 & -19.0 & & 6.0 & & 21.1 & 4.78 & 0.0000048 \\
\hline & & 3.32 & -19.0 & & 8.5 & & 17.1 & 3.89 & 0.0000074 \\
\hline & & 3.57 & -19.0 & & $>10.0$ & $\mathrm{f}$ & 16.0 & 3.64 & 0.0000085 \\
\hline & & 3.49 & -19.0 & & $<10.0$ & & 16.3 & 3.71 & 0.0000081 \\
\hline \multirow[t]{4}{*}{0.830} & 64.0 & 2.30 & -19.1 & & 7.2 & & 28.8 & 6.55 & 0.000004 \\
\hline & & 2.71 & -19.1 & & 8.5 & & 24.6 & 5.59 & 0.000005 \\
\hline & & 2.99 & -19.1 & & $>10.0$ & $f$ & 22.4 & 5.09 & 0.000006 \\
\hline & & 2.87 & -19.1 & & $<10.0$ & & 23.3 & 5.30 & 0.000006 \\
\hline \multirow[t]{4}{*}{0.484} & 37.6 & 4.31 & -20.4 & & $\begin{array}{l}6.8 \\
. \quad 6.8\end{array}$ & & 9.7 & 2.17 & 0.000013 \\
\hline & & 5.00 & -18.0 & & 9.1 & & 8.5 & 1.97 & 0.000016 \\
\hline & & 5.49 & $-1 . .9$ & & $>10.0$ & $f$ & 7.9 & 1.83 & 0.000020 \\
\hline & & 5.41 & $-1 \% .9$ & & $<10.0$ & & 8.0 & 1.85 & 0.000019 \\
\hline \multirow{3}{*}{0.623} & 48.0 & 3.36 & -18.9 & & 7.3 & & 15.3 & 3.48 & 0.000007 \\
\hline & & 4.30 & -18.2 & & $>10.0$ & $\mathrm{f}$ & 12.2 & 2.83 & 0.000012 \\
\hline & & 4.17 & -18.2 & & $<10.0$ & & 12.5 & 2.90 & 0.000011 \\
\hline \multirow[t]{2}{*}{0.761} & 58.6 & 3.35 & $-1 \varepsilon .2$ & & $>10.0$ & $\mathrm{f}$ & 18.5 & 4.28 & 0.000007 \\
\hline & & 3.01 & $-1 \varepsilon .2$ & & 8.8 & & $20.5^{\circ}$ & 4.75 & 0.000006 \\
\hline
\end{tabular}

$a_{\text {STP }}=70^{\circ} \mathrm{F}, 1 \mathrm{~atm}$. 


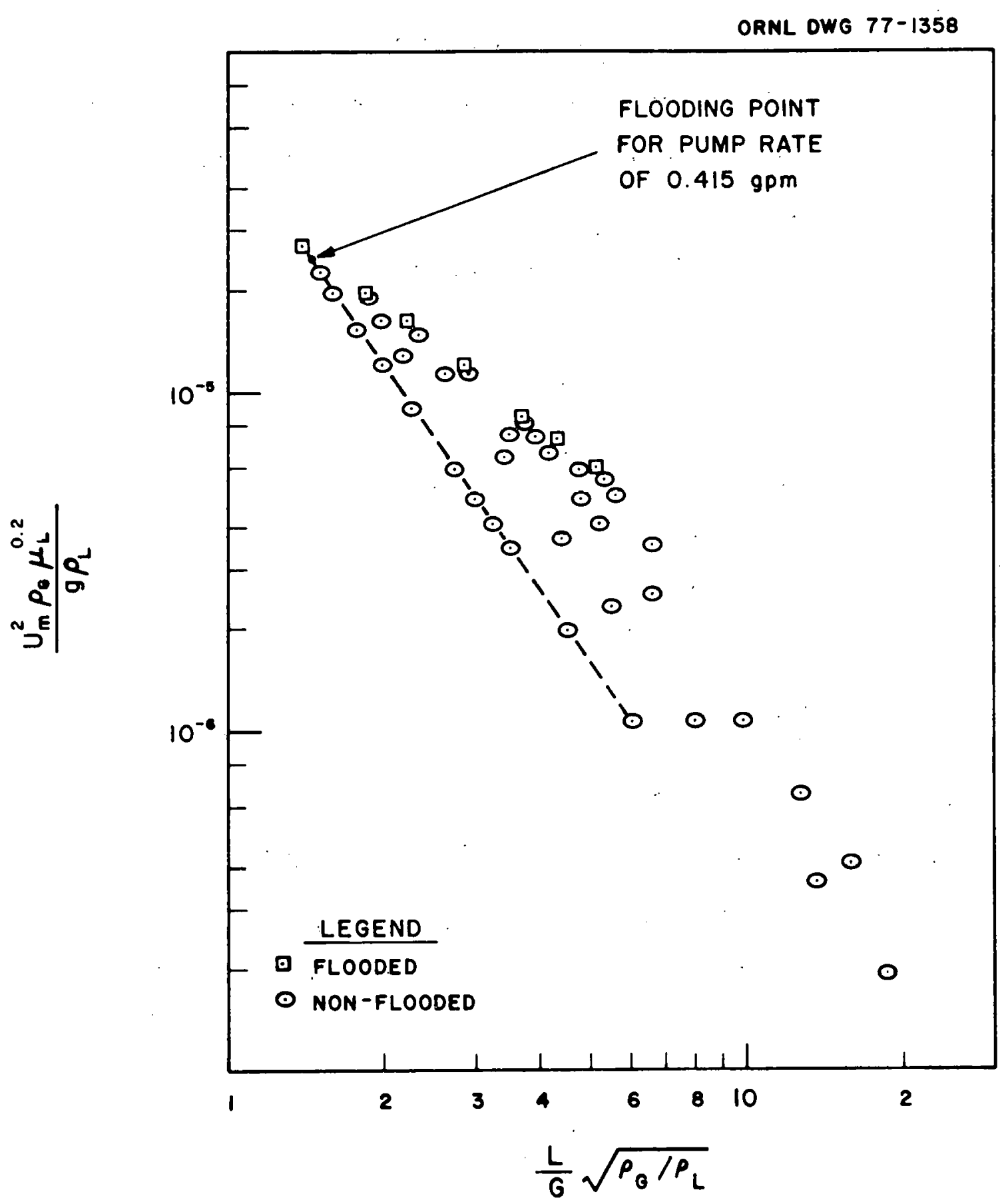

Fig. B-1. Flooding point determination. 
This correlation differs from that of Sherwood, Shipley, and Holloway in that the packing factor normally included in the ordinate value has been neglected. The nominal flooding point for each liquid flow rate was determined as the midpoint between the lowest gas flow that caused flooding and the highest gas flow for which the column was not flooded. Figures $B-2$ and $B-3$ present the resulting data as plots of $\Delta P$ vs $G / \emptyset$ and $G / \varnothing$ vs $L \emptyset / G$, respectively,

where

$$
\begin{aligned}
\Delta P & =\text { pressure drop, in } \mathrm{H}_{2} \mathrm{O} / \mathrm{ft} \text { packing, } \\
G & =\text { vapor rate } \mathrm{lb} / \mathrm{hr} \cdot \mathrm{ft} \mathrm{t}^{2}, \\
\emptyset & =\rho_{G} / 0.075, \\
\rho_{G} & =\text { gas-phase density, } \mathrm{lb} / \mathrm{ft}^{3}, \\
L & =\text { liquid rate, } \mathrm{lb} / \mathrm{hr} \cdot \mathrm{ft}^{2} .
\end{aligned}
$$

\section{B.2 References for Appendix B}

1. A. S. Faust et al., Principles of Unit Operations, pp. 269-70, Wilcy; New York, 1970.

2. R. H. Perry and C. H. Chilton, Chemical Engineers Handbook, 5th ed., p. 18-22, McGraw-Hill, New York, 1973. 
ORNL DWG 77-1357

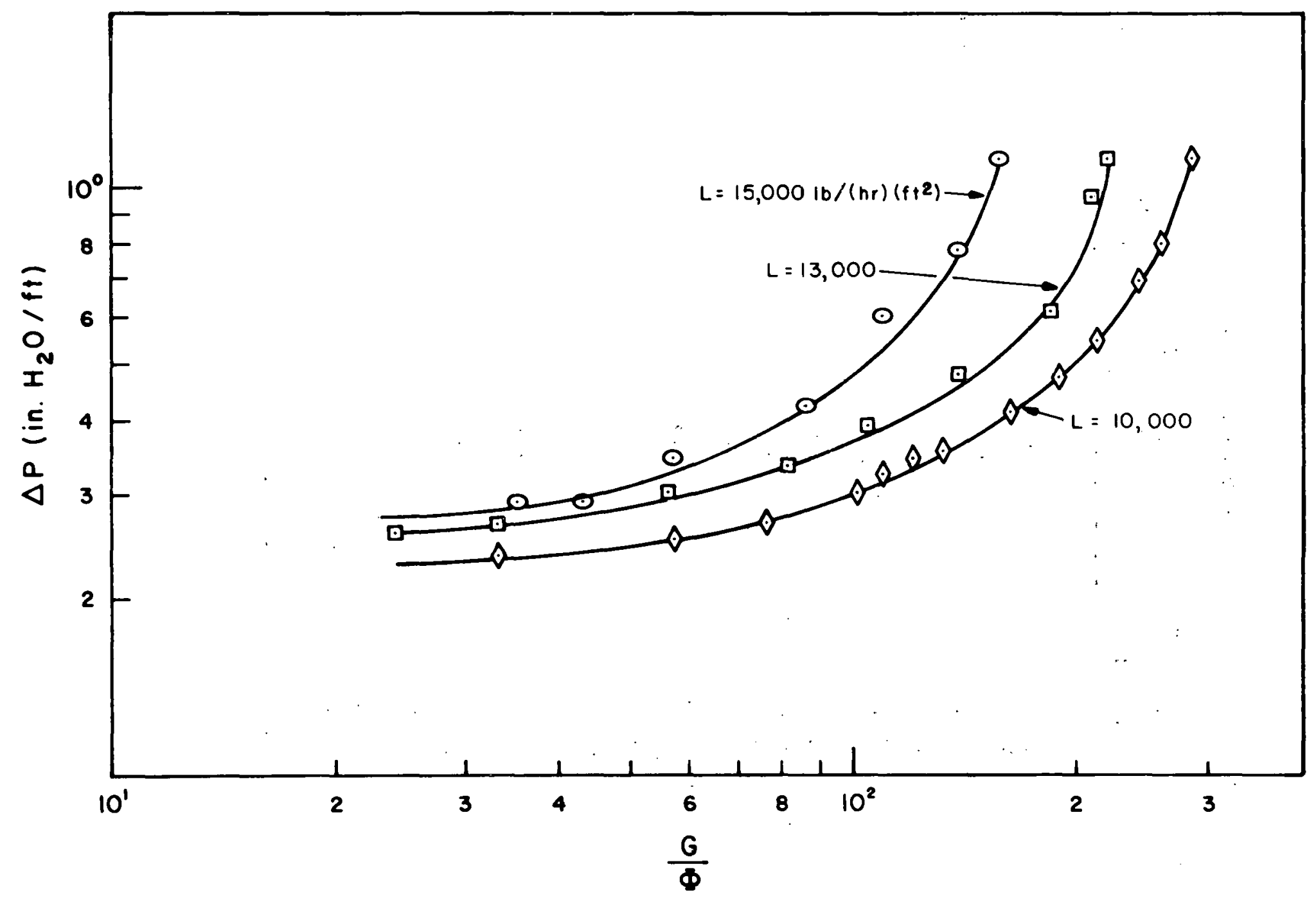

Fig. B-2. PRO-PAK loading curve. 
Table B-2. Data used in Figure B-2

\begin{tabular}{ccc}
\hline $\begin{array}{l}\Delta \mathrm{P} \\
\left.\text { (in. } \mathrm{H}_{2} \mathrm{O} / \mathrm{ft}\right)\end{array}$ & $\begin{array}{c}\mathrm{G} / \varnothing \\
\left(\text { lbs } / \mathrm{hr} \cdot \mathrm{ft}^{2}\right)\end{array}$ & $\begin{array}{c}\text { Flooded } \\
(\mathrm{f}=\text { yes })\end{array}$ \\
\hline & & \\
0.237 & 33 & \\
0.253 & 57 & \\
0.270 & 76 & \\
0.304 & 101 & \\
0.327 & 109 & \\
0.349 & 120 & \\
0.360 & 131 & \\
0.417 & 162 & \\
0.479 & 189 & \\
0.552 & 212 & \\
0.698 & 241 & \\
0.811 & 259 & \\
$>1.13$ & 284 & \\
0.259 & 24 & \\
0.270 & 33 & \\
0.304 & 56 & \\
0.338 & 81 & \\
0.394 & 104 & \\
0.484 & 138 & \\
0.619 & 184 & \\
0.989 & 208 & \\
$>1.13$ & 219 & \\
0.293 & 35 & \\
0.293 & 43 & \\
0.349 & 57 & \\
0.428 & 86 & \\
0.608 & 109 & \\
0.788 & 138 & \\
$>1.13$ & & \\
& & \\
\hline
\end{tabular}


ORNL DWG 77-1356

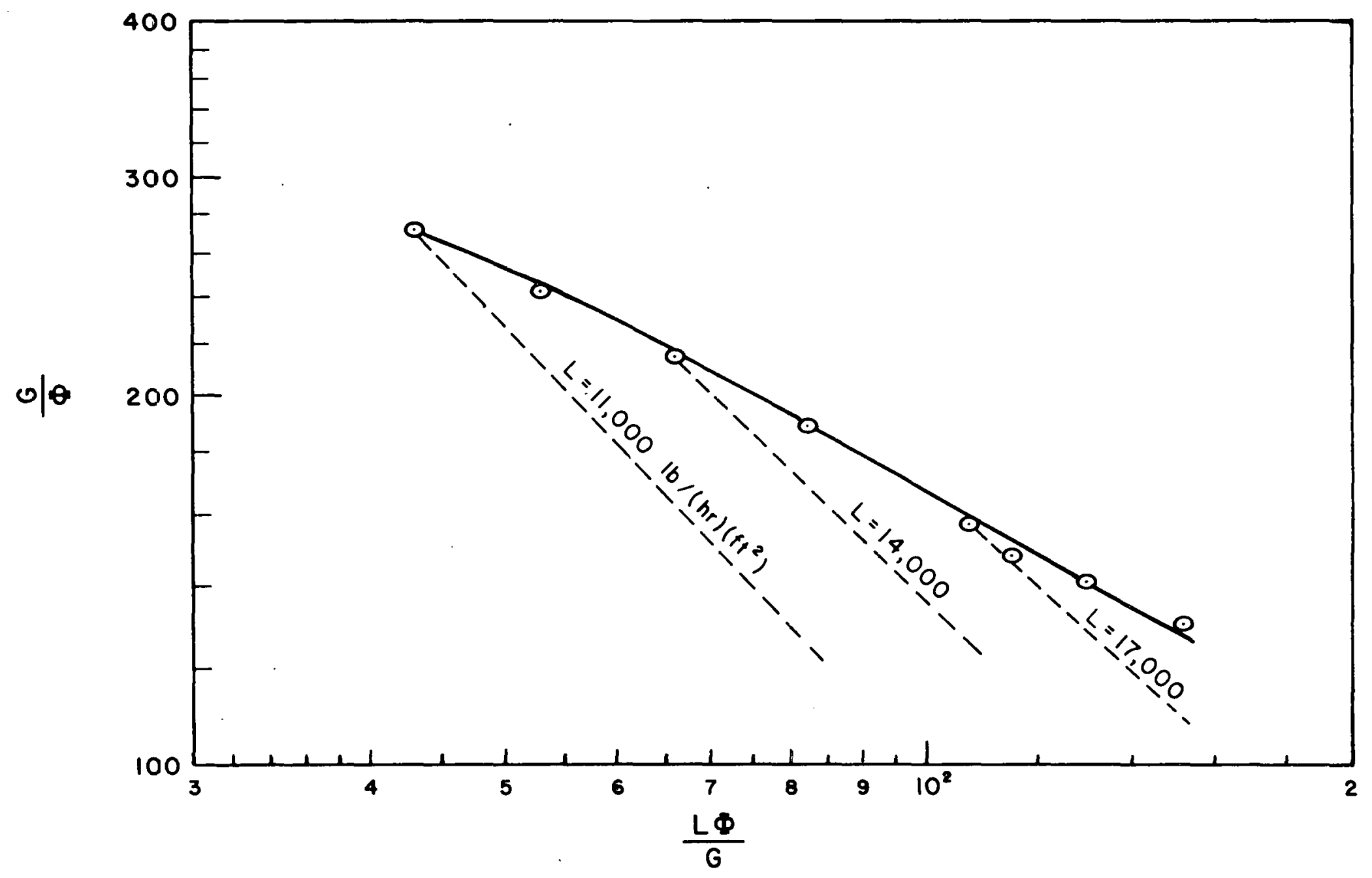

Fig. B-3. PRO-PAK flooding curve. 
Table B-3. Natta used in Figure $\mathrm{B}-3$

\begin{tabular}{cc}
\hline $\begin{array}{c}\mathrm{G} / \emptyset \\
\left(1 \mathrm{~b} / \mathrm{hr} \cdot \mathrm{ft}^{2}\right)\end{array}$ & $\mathrm{L} \emptyset / \mathrm{G}$ \\
\hline 130 & 152 \\
141 & 130 \\
148 & 115 \\
157 & 107 \\
188 & 82 \\
214 & 66 \\
242 & 53 \\
272 & 43 \\
\hline
\end{tabular}




\section{APPENDIX C: MASS TRANSFER CALCULATIONS}

The data analysis and the assumptions associated with it have been discussed in great detail previously in Campaign III. ${ }^{1}$ Consequently, the data-analysis model will be discussed here only as it contributes to the clarity of the data presented.

\section{C.1 Stripping Studies}

The analysis of the two-column stripping studies is similar to the analysis of the stripping data in Campaign III except that the 2-in. fractionator has been substituted for the 3-in. stripper. Consequently, only the model highlights will be presented here. To aid in the analysis, a schematic of the two-column system is shown in Fig. C-1. The streams are as follows:
(1)
Absorber column liquid feed,
(2)
System feed-gas,
(3)
Liquid leaving the absorber packing,
(4)
Vapor entering the absorber packing,
(5)
Tiquid entering the absorber packing,
(6)
Vapor leaving the absorber packing,
(7)
Liquid feed to fractionator column,
(8)
Absorber column off-gas,
(9)
Fractionator column off-gas,
(10)
Liquid leaving the fractionator packing,
(11)
Vapor entering the fractionator packing, 


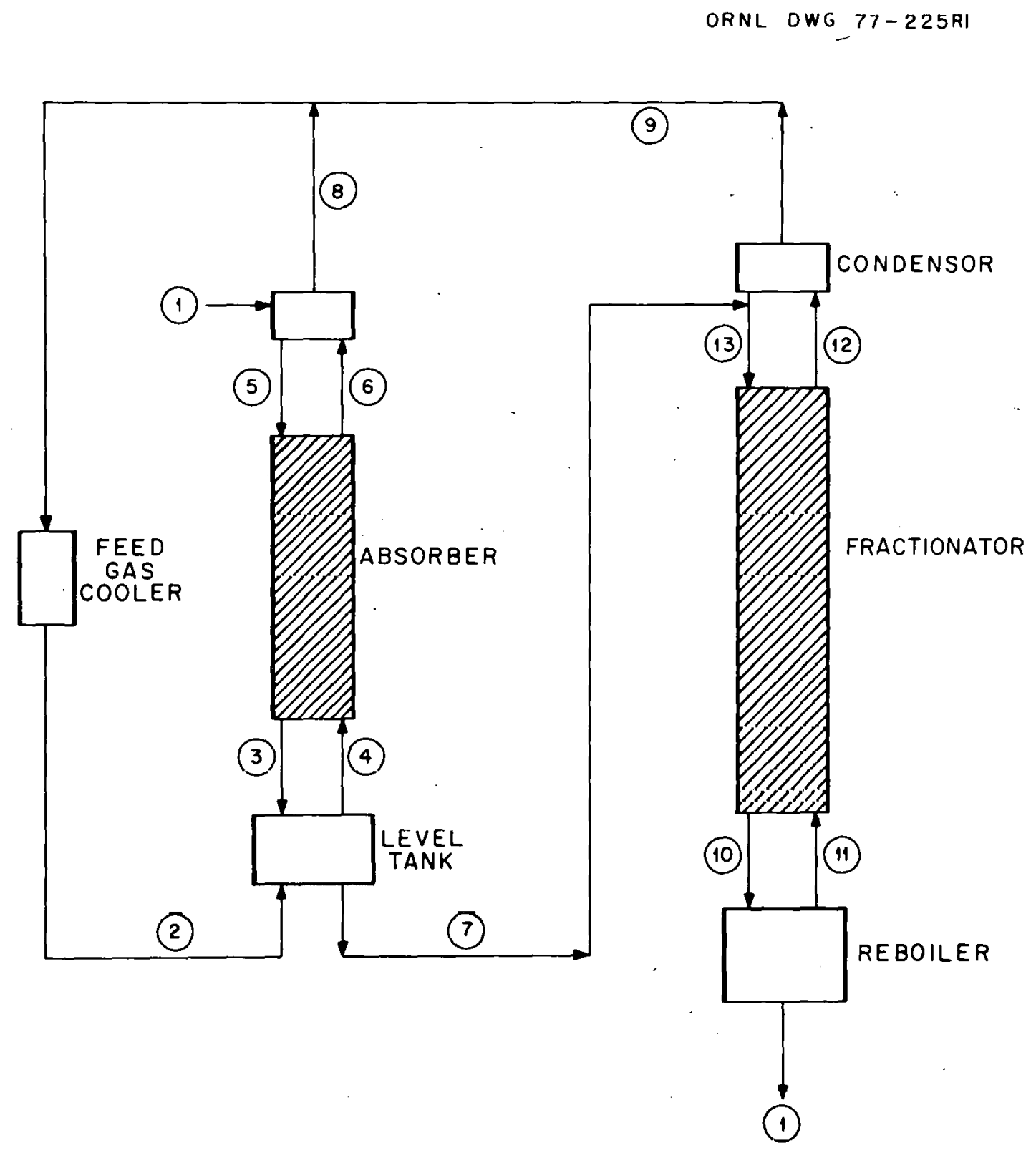

Fig. C-1. Schematic of the two-column system used in the strcam analysis. 
(12) Vapor leaving the fractionator packing, and

(13) Liquid entering the fractionator packing.

During the experiments, only streams 2,8 , and 9 could be identified by both flow rate (via calibrated rotameters) and composition (via sampling and analysis). The resulting component material balance from these streams gave an average of 99 and $97 \%$ for oxygen and krypton, respectively. Consequently, the composition normalization used in Campaign III was not used here. The off-gas data and resulting material balances are shown in Table $\mathrm{C}-2$.

The determination of flow rates and compositions of streams $1,7,10$, 11, 12 and 13 is identical to that in Campaign III. The results of these calculations are shown in Tables $\mathrm{C}-3$ through $\mathrm{C}-6$.

With the major streams defined as to flow rate and composition, the pertinent mass transfer information can now be calculated. The "stripper" column decontamination factor $\left(\mathrm{DF}_{c}\right)$ becomes

$$
\mathrm{DF}_{\mathrm{c}}=\frac{\mathrm{x}_{13}}{\mathrm{x}_{10}} \text {, }
$$

where $\mathrm{x}_{13}$ abd $\mathrm{x}_{10}$ are the krypton concentrations of the indicated streams. An overall decontamination factor $\left(\mathrm{DF}_{0}\right)$ is calculated to include the effects of the reboiler and column condenser by the following equation:

$$
\mathrm{DF}_{0}=\frac{\mathrm{Q}_{7} \mathrm{x}_{7}}{\mathrm{Q}_{1} \mathrm{x}_{1}}
$$


Table C-2. Gas stream values for stripper experiments

\begin{tabular}{|c|c|c|c|c|c|c|c|c|c|c|c|}
\hline \multirow{2}{*}{$\begin{array}{l}\text { Experiment } \\
\text { No. }\end{array}$} & \multicolumn{3}{|c|}{$\begin{array}{c}\text { Measured }{ }^{85_{\mathrm{Kr}} \text { corcentration }} \\
\text { (prb) }\end{array}$} & \multicolumn{3}{|c|}{ Measured $\mathrm{O}_{2}$ concentration } & \multicolumn{3}{|c|}{$\begin{array}{l}\text { Measured flow rate } \\
\qquad(\operatorname{scfm})^{a}\end{array}$} & \multicolumn{2}{|c|}{ Balance factor } \\
\hline & $\overline{\text { Stream } 2}$ & Stream $\varepsilon$ & $\overline{\text { Stream } 9}$ & Stream ? & Stream 8 & $\overline{\text { Stream } 9}$ & $\overline{\text { Stream } 2}$ & Stream 8 & $\overline{\text { Stream } 9}$ & $\mathrm{O}_{2}$ & $\mathrm{Kr}$ \\
\hline C4-206 & 5.9 & J.CO5 & 11.6 & 4.5 & 2.8 & 7.9 & 4.04 & 2.49 & 1.47 & 1.02 & 0.72 \\
\hline$C 4-214$ & 5.0 & $0 . \cos$ & 14.1 & 4.0 & 2.7 & 6.7 & 4.20 & 2.72 & 1.47 & 1.04 & 0.99 \\
\hline$C 4-221$ & 4.6 & $0 . \cos$ & 12.7 & $E .6$ & 3.1 & 9.5 & 4.19 & 2.71 & 1.46 & 0.96 & 0.97 \\
\hline$C 4-228$ & 39.7 & 0.65 & 249.7 & $1 \epsilon .0$ & c. 5 & 25.0 & 4.25 & 2.71 & 1.49 & 0.93 & 0.98 \\
\hline C4-237 & 58.8 & 0.04 & 206.6 & $1 z .3$ & 7.6 & 20.2 & 4.10 & 2.58 & 1.53 & 1.00 & 1.12 \\
\hline C4-244 & 46.9 & D. & 138.8 & 7.7 & 4.6 & 12.5 & 4.13 & 2.63 & 1.46 & 0.96 & 1.05 \\
\hline
\end{tabular}

${ }^{a} \operatorname{STP}=1$ atm, $70^{\circ} \mathrm{F}$. 
Table C-3. Equivalent pump rate (stream 1) for stripper experiments

\begin{tabular}{cccc}
\hline $\begin{array}{c}\text { Experiment } \\
\text { No. }\end{array}$ & $\begin{array}{c}\text { Pump rate } \\
(\mathrm{gpm})\end{array}$ & $\begin{array}{c}\text { Temperature } \\
\left({ }^{\circ} \mathrm{C}\right)\end{array}$ & $\begin{array}{c}\text { Stream } 1 \\
(\mathrm{scfm})^{\mathrm{a}}\end{array}$ \\
\hline $\mathrm{C} 4-206$ & 0.415 & -29.4 & 32.45 \\
$\mathrm{C} 4-214$ & 0.415 & -29.4 & 32.45 \\
$\mathrm{C} 4-221$ & 0.415 & -29.3 & 32.43 \\
$\mathrm{C} 4-228$ & 0.415 & -29.3 & 32.43 \\
$\mathrm{C} 4-237$ & 0.415 & -29.0 & 32.39 \\
$\mathrm{C} 4-244$ & 0.415 & -30.5 & 32.60 \\
\hline
\end{tabular}

${ }^{a}$ STP $=1$ atm, $70^{\circ} \mathrm{F}$. 
Table C-4. Calculated fractionator liquid feed fui stripping experiments

\begin{tabular}{|c|c|c|c|c|c|c|}
\hline \multirow{2}{*}{$\begin{array}{c}\text { Experiment } \\
\text { No. }\end{array}$} & \multirow[b]{2}{*}{ - } & \multirow[b]{2}{*}{$\begin{array}{c}\mathrm{Q}_{7} \\
(\operatorname{scfm})^{a}\end{array}$} & \multicolumn{2}{|c|}{$\begin{array}{c}\text { Measured } \\
\text { concentrations }\end{array}$} & \multicolumn{2}{|c|}{$\begin{array}{c}\text { Calculated } \\
\text { concentrations }\end{array}$} \\
\hline & & & $\begin{array}{l}{ }_{2} \\
(\%)\end{array}$ & $\begin{array}{l}\text { Krypton } \\
(\mathrm{pph})\end{array}$ & $\begin{array}{l}\mathrm{O}_{2} \\
(\%)\end{array}$ & $\begin{array}{l}\text { Krypton } \\
\text { (ppb) }\end{array}$ \\
\hline$C 4-206$ & & 33.91 & 0.27 & 0.72 & 0.33 & 0.70 \\
\hline$C 4-214$ & & 33.92 & 0.39 & 0.63 & 0.27 & 0.62 \\
\hline$C 4-221$ & $\cdots$ & 33.89 & 0.38 & 0.59 & 0.55 & 0.57 \\
\hline$C 4-228$ & & 33.92 & 0.39 & 11.15 & 1.24 & 11.23 \\
\hline$C_{4}-237$ & & 33.92 & 0.27 & 8.24 & 0.91 & 8.31 \\
\hline$C 4-244$ & & 34.06 & 0.26 & 5.66 & 0.58 & 5.66 \\
\hline
\end{tabular}

$\mathrm{a}_{\mathrm{STP}}=1$ atm, $70^{\circ} \mathrm{F}$. 
Table C-5. Calculated fractionator bottom information for stripping studies

\begin{tabular}{|c|c|c|c|c|c|c|c|}
\hline \multirow{3}{*}{$\begin{array}{c}\text { Experiment } \\
\text { No. }\end{array}$} & \multirow{3}{*}{\multicolumn{2}{|c|}{$\begin{array}{c}\text { Calculated flow } \\
\text { rates } \\
(\mathrm{scfm})^{\mathrm{a}}\end{array}$}} & \multicolumn{3}{|c|}{ Measured concentrations } & \multicolumn{2}{|c|}{ Calculated concentrations } \\
\hline & & & \multirow{2}{*}{$\begin{array}{c}\frac{\text { Stream 1 }}{\text { Krypton }} \\
\text { (ppb) }\end{array}$} & \multirow{2}{*}{$\frac{\text { Stream } 10}{\begin{array}{c}\text { Krypton } \\
\text { (ppb) }\end{array}}$} & \multirow{2}{*}{$\frac{\text { Stream ll }}{\begin{array}{c}\text { Krypton } \\
\text { (ppb) }\end{array}}$} & \multirow{2}{*}{ 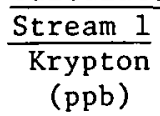 } & \multirow{2}{*}{ 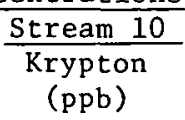 } \\
\hline & Stream 10 & & & & & & \\
\hline$C_{4}^{\prime}-206$ & 37.16 & 4.74 & 0.002 & 0.004 & 0.0062 & 0.0006 & 0.0013 \\
\hline $\mathrm{C} \dot{4}-2 \mathrm{i} 4$ & 36.95 & 4.49 & 0.002 & 0.002 & 0.002 & 0.0002 & 0.0005 \\
\hline$C_{4}-221$ & 36.59 & 4.14 & 0.0005 & 0.002 & 0.004 & 0.0004 & 0.0008 \\
\hline $\mathrm{C} 4-228$ & 36.54 & 4.11 & 0.001 & 0.003 & 0.017 & 0.0016 & 0.003 \\
\hline C4-237 & 36.67 & 4.29 & 0.006 & 0.004 & 0.03 & 0.0029 & 0.0061 \\
\hline C4-244 & 36.41 & 3.85 & 0.04 & 0.08 & 0.5 & 0.048 & 0.096 \\
\hline
\end{tabular}

${ }^{\mathrm{a}} \mathrm{STP}=1 \mathrm{~atm}, \quad 20^{\circ} \mathrm{F}$. 
Table $:-6$. Calculated fractionator top information for stripping studies

\begin{tabular}{|c|c|c|c|c|c|}
\hline \multirow{3}{*}{$\begin{array}{l}\text { Experiment } \\
\text { No. }\end{array}$} & \multirow{2}{*}{\multicolumn{2}{|c|}{$\begin{array}{c}\text { Calculated flow rate } \\
(\mathrm{scfm})^{\mathrm{a}}\end{array}$}} & \multicolumn{2}{|c|}{ Measured concentration } & \multirow{3}{*}{ 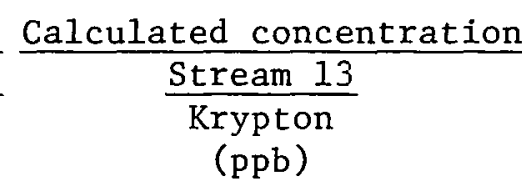 } \\
\hline & & & \multirow{2}{*}{$\frac{\text { Stream } 12}{\begin{array}{c}\text { Krypton } \\
(\mathrm{ppb})\end{array}}$} & \multirow{2}{*}{$\begin{array}{l}\frac{\text { Stream } 13}{\text { Krypton }} \\
(\mathrm{ppb})\end{array}$} & \\
\hline & Stream 13 & Strean. 12 & & & \\
\hline$C 4-206$ & 37.16 & 4.74 & 4.05 & 0.49 & 0.52 \\
\hline$C 4-214$ & 36.95 & 4.45 & 3.30 & 0.39 & 0.40 \\
\hline$C 4-221$ & 36.59 & $4.1<$ & 3.43 & 0.36 & 0.39 \\
\hline$C 4-228$ & 36.54 & 4.11 & 55.97 & 7.43 & 6.30 \\
\hline$C 4-237$ & $36.6^{7}$ & 4.29 & 44.13 & 5.26 & 5.16 \\
\hline$C 4-244$ & 36.41 & 3.85 & 36.55 & 3.65 & 3.90 \\
\hline
\end{tabular}

${ }^{\mathrm{a}} \mathrm{STP}=11 \mathrm{~atm}, 70^{\circ} \bar{s}$. 
where

$$
\begin{aligned}
& Q_{7}=\text { flow rate of stream } 7, \operatorname{scfm}, \\
& x_{7}=\text { krypton concentration of stream } 7, p p b, \\
& Q_{1}=\text { flow rate of stream } 1, \operatorname{scfm}, \\
& x_{1}=\text { krypton concentration of stream } 1, p p b .
\end{aligned}
$$

A height of a transfer unit (HTU) value is calculated using: ${ }^{2}$

$$
\begin{gathered}
\text { HTU }=\mathrm{Z} / \mathrm{NTU} \\
\mathrm{NTU}=\frac{\mathrm{x}_{i}-\mathrm{x}_{\mathrm{o}}}{\left(\mathrm{x}-\mathrm{x}^{*}\right)_{\ell \mathrm{m}}}
\end{gathered}
$$

and

$$
\left(x-x^{*}\right)_{\operatorname{lm}}=\frac{\left(x_{0}-x_{0}^{*}\right)-\left(x_{i}-x_{i}^{*}\right)}{\ln \left[\frac{x_{0}-x_{0}^{*}}{x_{i}-x_{i}^{*}}\right]},
$$

where

$$
\begin{aligned}
\mathrm{Z} & =\text { height of column packing, } \mathrm{ft}, \\
\mathrm{NTU} & =\text { number of transfer units, } \\
\mathrm{x}_{\mathrm{i}} & =\text { inlet liquid } \mathrm{Kr} \text { concentration, } \\
\mathrm{x}_{0} & =\text { outlet liquid } \mathrm{Kr} \text { concentration, } \\
\mathrm{x}_{\mathbf{i}}{ }^{*} & =\mathrm{Kr} \text { concentration in equilibrium with the inlet gas, } \\
\mathrm{x}_{0}{ }^{*} & =\mathrm{Kr} \text { concentration in equilibrium with the outlet gas. }
\end{aligned}
$$

For stripping studies,

$$
\begin{aligned}
\mathrm{z} & =8.88 \mathrm{ft}, \\
\mathrm{x}_{\mathrm{i}} & =\text { krypton concentration of stream } 13, \mathrm{pph},
\end{aligned}
$$




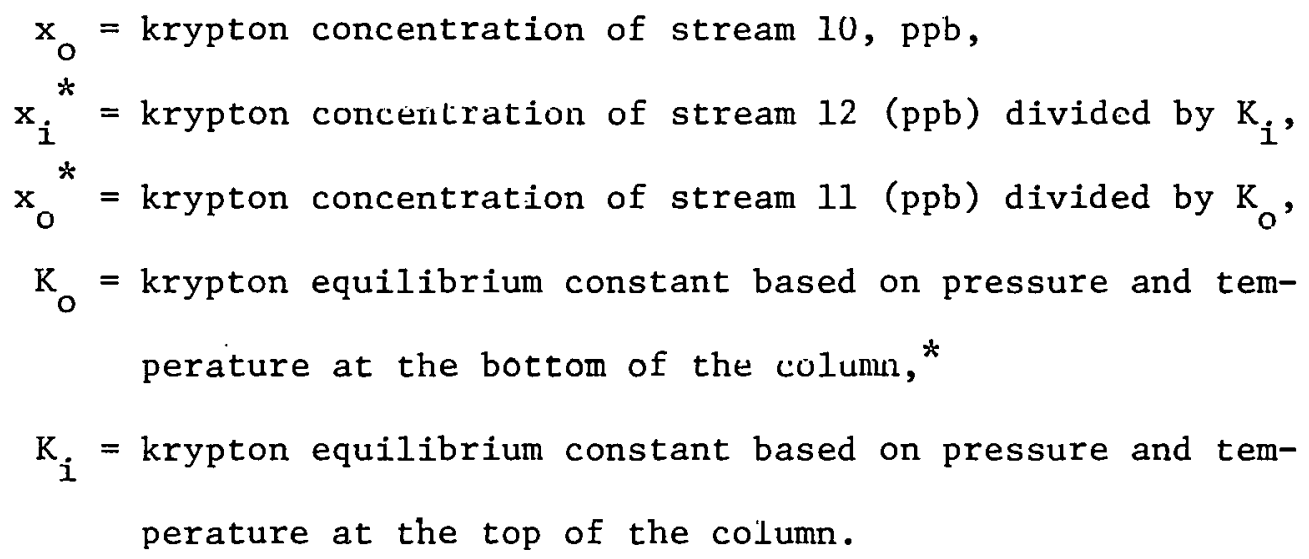

A column stripping factor $(\mathrm{VK} / \mathrm{L})$ is defined by:

$$
\frac{\mathrm{VK}}{\mathrm{L}}=\frac{\mathrm{Q}_{11} \mathrm{~K}_{\mathrm{avg}}}{\mathrm{Q}_{10}},
$$

where

$$
\begin{aligned}
\mathrm{Q}_{11} & =\text { flow rate of stream } 11, \text { scfm } \\
\mathrm{K}_{\text {avg }} & =\left(\mathrm{K}_{1}+\mathrm{K}_{0}\right) / 2, \\
\mathrm{Q}_{10} & =\text { flow rate of stream } 10, \text { scfm. }
\end{aligned}
$$

\section{C.2 Fractionation Studies}

The data analysis for fractionation studies is simflar to that of the stripping experiments, but the system now contains all three columns. To aid in the analysis, a schematic of the three-column system is shown in Fig. C-2. The streams are similar to those in Fig. C-1, with the following addiclons:

\footnotetext{
*All equilibrium constants used in this report are calculated using
} the Glass model. 3 
ORNL_ DWG $77-1352$

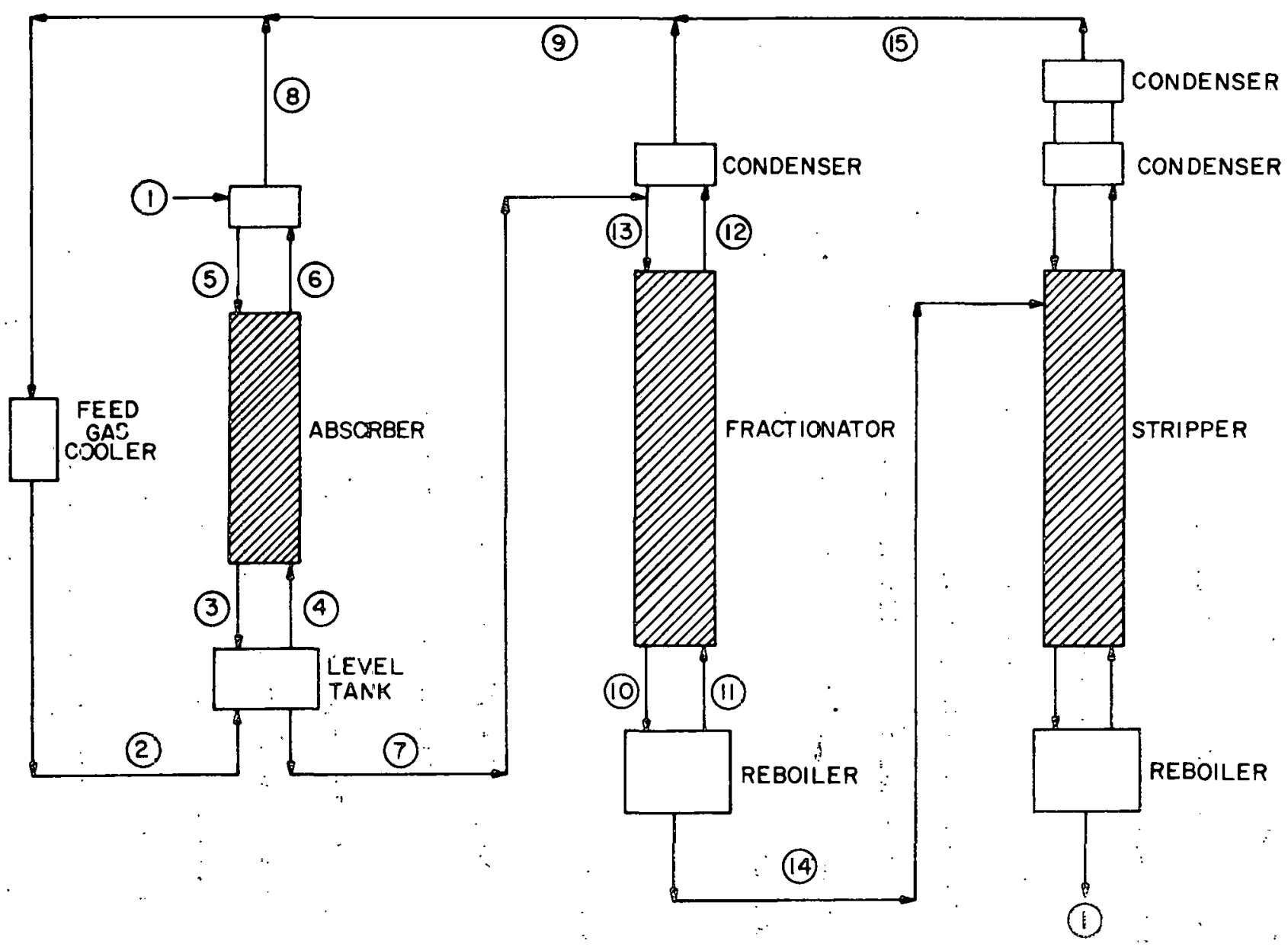

Fig. C-2. Schematic of three-column system used in data analysis. 
(14) Liquid feed to the stripper
(15) Stripper off-gas.

The off-gas component material balance data (streams 2, 8, 9, 15) are shown in Table C-7. Again, composition normalization was omitted due to the average material balance values of 1.04 and 0.97 for $O_{2}$ and $\mathrm{Kr}$, respectively.

The determination of flow rates and compositions of streams 1,7 , 10, 11,12 , and 13 is identical to that in the stripping experiments with the following modification, stream 1 (i.e., pump rate) is no longer equal to the liquid leaving the fractionator reboiler (stream 14). Stream 14 is defined by an overall material balance around the stripper column:

$$
Q_{14}=Q_{15}+Q_{1}
$$

where

$$
\begin{aligned}
& Q_{15}=\text { stripper off-gas, scfm, and } \\
& Q_{1}=\text { liquid leaving the stripper reboller, sce Im. }
\end{aligned}
$$

The calculations for the other streams proceed as in the Campaign III analysis substituting $Q_{14}$ for $U_{1}$ whenever the liyuid rate leaving the fractionator reboiler is needed. The results of these calculations are shown in Tables C-8 through $\mathrm{C}-11$.

The fractionator column $\mathrm{DF}_{\mathrm{c}}$, HTU, and stripping factor are calculated using Eys. (1), (3), (4), (5), and (6) with the following modifications: 
Gable C-7. Gas-stream values for fractionation stedies

\begin{tabular}{|c|c|c|c|c|c|c|c|c|c|c|c|c|c|c|}
\hline \multirow{2}{*}{$\begin{array}{l}\text { Experiment } \\
\text { No. }\end{array}$} & \multicolumn{4}{|c|}{$\begin{array}{c}\text { Measured } \begin{array}{c}{ }^{85} \mathrm{Kr} \text { concentration } \\
(\mathrm{p} p \mathrm{~b})\end{array} \\
\end{array}$} & \multicolumn{4}{|c|}{$\begin{array}{c}\text { Measured } \mathrm{O}_{2} \text { concentration } \\
(\%)\end{array}$} & \multicolumn{4}{|c|}{$\begin{array}{l}\text { Measured flow rate } \\
(\operatorname{scfm})^{\mathrm{a}}\end{array}$} & \multicolumn{2}{|c|}{ Balance factor } \\
\hline & Stream 2 & stream 8 & 3 Stream 9 & Stream 15 & Stream 2 & 2 Stream 8 & 3 Stream 9 & Strean 15 & Stream 2 & Stream 8 & Stream 9 & Stream 15 & $\mathrm{O}_{2}$ & $\mathrm{Kr}$ \\
\hline$C 4-171$ & 26.10 & 15.2 & -- & 54.7 & 4.7 & 2.6 & -- & 9.5 & 5.27 & 3.68 & -- & 1.61 & 1.00 & 1.05 \\
\hline$C 4-181$ & 11.44 & 1.74 & 28.92 & 24.62 & 11.9 & 7.3 & 1.14 & 25.2 & 5.97 & 3.35 & 0.77 & 1.69 & 0.96 & 1.02 \\
\hline C4-188 & 10.74 & 0.11 & 31.89 & 19.10 & 6.2 & 3.9 & 2.1 & 20.0 & 5.76 & 3.22 & 0.78 & 1.70 & 1.35 & 0.93 \\
\hline C4-197 & 9.80 & 0.013 & 29.50 & 17.50 & 9.9 & 6.0 & 2.4 & 20.4 & 5.65 & 3.02 & 0.78 & 1.67 & 0.96 & 0.94 \\
\hline$C 4-251$ & 27.70 & 0.35 & 52.50 & 54.20 & 6.4 & 5.4 & 0.8 & 10.5 & 5.33 & 2.82 & 0.74 & 1.67 & 1.00 & 0.88 \\
\hline C4-259 & 22.50 & 0.13 & 60.40 & 42.50 & 7.4 & 6.7 & 1.4 & 11.6 & 5.24 & 2.67 & 0.74 & 1.68 & 0.99 & 0.99 \\
\hline$C 4-266$ & 20.70 & 0.09 & 56.00 & 33.70 & 7.3 & 6.3 & 1.5 & 12.0 & 5.17 & 2.59 & 0.74 & 1.67 & 0.99 & 0.97 \\
\hline
\end{tabular}

${ }^{a} \operatorname{STP}=70^{\circ} \mathrm{F}, 1$ atm. 
Table C-8. Equivalent pump rate for fractionation experiments

\begin{tabular}{cccc}
\hline $\begin{array}{c}\text { Experiment } \\
\text { No. }\end{array}$ & $\begin{array}{c}\text { Pump rate } \\
(\mathrm{gpm})\end{array}$ & $\begin{array}{c}\text { Temperature } \\
\left({ }^{\circ} \mathrm{C}\right)\end{array}$ & $\begin{array}{c}\mathrm{Q}_{1} \\
(\mathrm{scfm})\end{array}$ \\
\hline $\mathrm{C} 4-171$ & 0.5533 & -27.3 & 42.87 \\
$\mathrm{C} 4-181$ & 0.5533 & -26.3 & 42.69 \\
$\mathrm{C} 4-188$ & 0.5533 & -27.9 & 42.98 \\
$\mathrm{C} 4-197$ & 0.5533 & -24.1 & 42.28 \\
$\mathrm{C} 4-251$ & 0.4150 & -29.8 & 32.50 \\
$\mathrm{C} 4-259$ & 0.4150 & -29.9 & 32.52 \\
$\mathrm{C} 4-266$ & 0.4150 & -29.8 & 32.50 \\
\hline${ }_{\mathrm{STP}}=1 \mathrm{~atm}, 70^{\circ} \mathrm{F}$. & & &
\end{tabular}


Table C-9. Calculated fractionator liquid feed for fractionator experiments

\begin{tabular}{|c|c|c|c|c|c|}
\hline \multirow{2}{*}{$\begin{array}{c}\text { Experiment } \\
\text { No. }\end{array}$} & \multirow[b]{2}{*}{$\begin{array}{c}\mathrm{Q}_{7} \\
(\operatorname{scfm})^{\mathrm{a}}\end{array}$} & \multicolumn{2}{|c|}{$\begin{array}{c}\text { Measured } \\
\text { concentrations } \\
\end{array}$} & \multicolumn{2}{|c|}{$\begin{array}{c}\text { Calculated } \\
\text { concentrations }\end{array}$} \\
\hline & & $\begin{array}{l}\overline{\mathrm{O}_{2}} \\
(\%)\end{array}$ & $\begin{array}{c}\text { Krypton } \\
\text { (ppb) }\end{array}$ & $\begin{array}{l}\mathrm{O}_{2} \\
(\%)\end{array}$ & $\begin{array}{c}\text { Krypton } \\
\text { (ppb) }\end{array}$ \\
\hline $\mathrm{C} 4-1.7 .1$ & 44.48 & 0.06 & 4.66 & 0.35 & 1.84 \\
\hline C4-181 & 45.15 & 0.45 & 1.53 & 1.05 & 2.10 \\
\hline$C 4-188$ & 44.69 & 0.41 & 1.34 & 0.80 & 1.28 \\
\hline C4-197 & 44.73 & 0.38 & 1.19 & 0.80 & 1.17 \\
\hline$C 4-251$ & 34.91 & 0.40 & 3.35 & 0.54 & 3.71 \\
\hline$C 4-259$ & 34.94 & 0.37 & 3.55 & 0.59 & 3.32 \\
\hline$C 4-266$ & 33.24 & 0.31 & 3.17 & 0.64 & 3.12 \\
\hline
\end{tabular}

${ }^{a_{\mathrm{STP}}}=1 \mathrm{~atm}, 70^{\circ} \mathrm{F}$. 
Table C-10. Calculated bottom information for Eractionation stucies

\begin{tabular}{|c|c|c|c|c|c|c|c|c|c|c|c|c|}
\hline \multirow{4}{*}{$\begin{array}{c}\text { Experiment } \\
\text { No. }\end{array}$} & \multirow{3}{*}{\multicolumn{2}{|c|}{$\begin{array}{c}\text { Calcuiated } \bar{\Xi} 1 \mathrm{cw} \\
=\text { ates } \\
(\text { scfm })^{a}\end{array}$}} & \multicolumn{6}{|c|}{ Measured concentrations } & \multicolumn{4}{|c|}{ Calculated concentrations } \\
\hline & & & \multicolumn{2}{|c|}{ Stream I't } & \multicolumn{2}{|c|}{ Stream 10} & \multicolumn{2}{|c|}{ Stream 11} & \multicolumn{2}{|c|}{ Stream 14} & \multicolumn{2}{|c|}{ Stream 10} \\
\hline & & & $\overline{\mathrm{O}_{2}}$ & & $\mathrm{O}_{2}$ & $\mathrm{Kr}$ & $\mathrm{O}_{2}$ & $\mathrm{Kr}$ & $\mathrm{O}_{2}$ & $\mathrm{Kr}$ & $\mathrm{O}_{2}$ & $\mathrm{Kr}$ \\
\hline & Stream $1 C$ & Stream 11 & $(\%)$ & $(\mathrm{ppb})$ & $(\%)$ & $(\mathrm{ppb})$ & $(\%)$ & $(\mathrm{ppb})$ & $(\%)$ & $(\mathrm{ppb})$ & $(\%)$ & $(\mathrm{ppb})$ \\
\hline$C 4-171$ & 45.71 & 2.84 & $0.00 z$ & 1. 59 & $C .006$ & 2.61 & 0.051 & 18.03 & 0.0028 & 1.94 & 0.0058 & 2.94 \\
\hline$C 4-181$ & 46.46 & 3.00 & $0.02 \Xi$ & 0.60 & $C .063$ & 1.07 & 0.435 & 7.15 & 0.024 & 0.77 & 0.05 & 1.18 \\
\hline$C 4-188$ & 48.08 & $2 . \subseteq 1$ & 0.061 & 0.65 & C..1I & 1.04 & 0.953 & 7.3 & 0.052 & 0.78 & 0.107 & 1.17 \\
\hline C4-197 & 46.02 & $2 . \subseteq 6$ & 0.05 & 0.53 & 0.1 & 0.90 & 0.739 & 6.3 & 0.041 & 0.68 & 0.086 & 1.04 \\
\hline$C 4-25 I$ & 35.49 & 2.2 .5 & 0.00605 & 1.27 & 0.0002 & 2.24 & 0.0005 & 15.4 & 0.00003 & 1.66 & 0.00006 & 2.53 \\
\hline$C 4-259$ & 35.26 & 2.01 & $0.01:$ & I. .59 & 0.033 & 2.3 & 0.377 & 17.8 & 0.021 & 1.91 & 0.041 & 2.82 \\
\hline$C 4-266$ & 34.53 & 2.03 & 0.00 & $=-37$ & 0.021 & 2.17 & 0.252 & 16.4 & 0.014 & 1.76 & 0.028 & 2.62 \\
\hline
\end{tabular}

${ }^{\mathrm{a}} \mathrm{STP}=1 \mathrm{~atm}, 70^{\circ} \mathrm{F}$. 
Table C-11. Calculated fractionator top information for fractionator studies

\begin{tabular}{|c|c|c|c|c|c|c|c|c|}
\hline \multirow{4}{*}{$\begin{array}{l}\text { Experiment } \\
\text { No. }\end{array}$} & \multirow{3}{*}{\multicolumn{2}{|c|}{$\begin{array}{c}\text { Calculated flow rate } \\
(\operatorname{scfm})^{a}\end{array}$}} & \multicolumn{4}{|c|}{ Measured concentration } & \multicolumn{2}{|c|}{ Calculated concentration } \\
\hline & & & \multicolumn{2}{|c|}{ Stream 12} & \multicolumn{2}{|c|}{ Stream 13} & \multicolumn{2}{|c|}{ Stream 13} \\
\hline & & & \multirow{2}{*}{$\begin{array}{l}\mathrm{O}_{2} \\
(\%)\end{array}$} & \multirow{2}{*}{$\frac{\mathrm{Kr}}{(\mathrm{ppb})}$} & \multirow{2}{*}{$\begin{array}{l}\mathrm{O}_{2} \\
(\%)\end{array}$} & \multirow{2}{*}{$\frac{\mathrm{Kr}}{(\mathrm{ppb})}$} & \multirow{2}{*}{$\begin{array}{l}\mathrm{O}_{2} \\
(\%)\end{array}$} & \multirow{2}{*}{$\begin{array}{c}\mathrm{Kr} \\
(\mathrm{ppb})\end{array}$} \\
\hline & Stream 13 & Strəam 12 & & & & & & \\
\hline C4 $4-171$ & 45.71 & 2.84 & 0.64 & 23.5 & 0.04 & 2.74 & 0.04 & 3.28 \\
\hline C4-181 & 46.46 & 3.00 & 9.9 & 10.2 & 0.23 & 1.05 & 0.66 & 1.38 \\
\hline$C 4-188$ & 48.08 & 2.91 & 5.6 & 8.7 & 0.25 & 1.01 & 0.39 & 1.26 \\
\hline C4-197 & 46.02 & 2.96 & 9.8 & 8.0 & 0.23 & 0.91 & 0.67 & 1.15 \\
\hline$C 4-251$ & 35.49 & 2.25 & 4.9 & 21.5 & 0.23 & 2.44 & 0.31 & 2.92 \\
\hline$C 4-259$ & 35.26 & 2.01 & 7.4 & 22.2 & 0.22 & 2.60 & 0.44 & 3.07 \\
\hline$C 4-266$ & 34.53 & 2.03 & 6.7 & 19.9 & 0.18 & 2.30 & 0.41 & 2.83 \\
\hline
\end{tabular}

${ }^{\mathrm{a}} \mathrm{STP}=70^{\circ} \mathrm{F}, 1 \mathrm{~atm}$. 
1) $x_{i}=O_{2}$ concentration of liquid stream $i$,

2) $x_{i}^{*}=O_{2}$ concentration of vapor in equilibrium with $x_{i}$,

3) $\mathrm{K}_{\mathrm{o}}=\mathrm{O}_{2}$ equilibrium constant based on pressure and temperature at the bottom of the column,

4) $\mathrm{K}_{\mathrm{i}}=\mathrm{O}_{2}$ equilibrium constant based on pressure and temperature at the top of the column.

The overall DF is calculated using Eq. (2) with the following modifications:

1) $\mathbf{x}_{\mathbf{i}}=\mathrm{O}_{2}$ concentration of stream $\mathbf{i}$,

2) $Q_{1}$ is replaced by $Q_{1,4^{\circ}}$.

\section{C.3 References for Append1x C}

1. T. M. Gilliam, V. L. Fowler, and D. J. Inman, Krypton Absorption in Liquid $\mathrm{CO}_{2}$ (KALC): Campaign III in the Experimental Engineering Section Off-Gas Decontamination Facility, ORNL/TM-5655 (September 1977).

2. R. E. Treybal, Mass Transfer Operations, 2nd ed., Pp. 250-53, McGraw-Hill, New York, 1968.

3. R. W. Glase, T. M. Gilliam, and V. L. Fowler, An Empirical Model for Calculating Vapor-L1quid Eyuilibrium and Associated Phase Enthalpy for the $\mathrm{CO}_{2}-{ }_{-}-\mathrm{Kr}-\mathrm{Xe}$ System for Application to the KALC Process, ORNL/TM-4947 (January 1976). 
ORNL/TM-5869

Dist. Category UC-77

\section{INTERNAL DISTRIBUTION}

1. R. E. Barker

2. B. J. Baxter

3. R. A. Bradley

4. R. E. Brooksbank

5. W. D. Burch

6. W. L. Carter

7. J. H. Coobs

8. F. E. Dearing

9. R. S. Eby

10. D. E. Ferguson

11. L. M. Ferris

12. M. J. Feldman

13. C. W. Forsberg

14-18. V. L. Fowler

19-28. T. M. Gilliam

29. R. W. Glass

30. W. S. Groenier

31. P. A. Haas

32. B. A. Hannaford

33. F. E. Harrington

34. C. C. Haws

35. V. Hoffstetler

36. B. Kanack

37-4l. D. J. Inman

42-49. P. R. Kasten

50. J. A. Klein

51. R. E. Leuze
52. K. H. Lin

53-54. A. L. Lotts

55. L. E. McNeese

56-57. K. J. Notz

58. R. L. Philippone

59. H. Postma

60. A. D. Ryon

61. C. D. Scott

62. J. W. Snider

63. M. J. Stephenson

64. D. B. Trauger

65. W. E. Unger

66. V. C. A. Vaughen

67. B. L. Vondra

68. M. E. Whatley

69-70. R. G. Wymer

71. 0. 0. Yarbro

72-73, Central Research Library

74. Document Reference Section

75-76. Laboratory Records

77. Laboratory Records, R.C.

78. ORNL Patent Section

79. G. R. Choppin (consultant)

80. E. L. Gaden, Jr. (consultant)

81. C. H. Ice (consultant)

82. L. E. Swabb, Jr. (consultant)

83. K. D. Timmerhaus (consultant)

EXTERNAL DISTRIBUTION

84. Research and Technical Support Division, DOE, ORO, P. O. BOx E, Oak Ridge, TN 37830

85. Director, Reactor Division, DOE, ORO, P. O. Box E, Oak Ridge, TN 37830

86-87. Director, Division of Reactor Development and Demonstration, DOE, Washington, D.C. 20545

88-264. Civen distribullun as shown in TID-4500 under Gas-Cooled Reactor Technology Category (25 copies - NTIS) 